\title{
HIGH PERFORMANCE FIBERS: A REVIEW ON CURRENT STATE OF ART AND FUTURE CHALLENGES
}

\author{
Hüseyin AVCI ${ }^{*}{ }^{*}$, Ahmed HASSANIN² ${ }^{2}$ Tamer HAMOUDA³ ${ }^{3}$ Ali KILIÇ4
}

${ }^{1}$ Eskişehir Osmangazi University, Faculty of Engineering and Architecture, Department of Metallurgical and Materials Engineering, Eskisehir, Turkey, ORCID No: https://orcid.org/0000-0002-2475-1963

2Textile Engineering Department, Alexandria University, Egypt, ORCID No: http://orcid.org/0000-0003-4253-7829

${ }^{3}$ Textile Research Division, National Research Centre, Egypt, ORCID No: http://orcid.org/0000-0003-3184-6212

4TEMAG Labs, Istanbul Technical University, Istanbul, Turkey, ORCID No: http://orcid.org/0000-0001-5915-8732

\begin{tabular}{ll} 
Keywords & DOI : http://dx.doi.org/10.31796/ogummf.558453 \\
\hline High performance, fibers, & Improving properties of polymeric and non-polymeric fibers, for example mechanical, \\
organic, inorganic, future & dimensional stability, thermal degradation, and etc. with understanding a recent \\
directions & theoretical investigation on the solid mechanism of single crystal growth leads to obtain \\
fiber-based products with unusual characteristics. Similarly, high performance fibers are & important engineering products and widely used due to their outstanding mechanical \\
property along with dimensional stability. They have found extensive use as fiber & reinforcement and can be utilized in many applications such as cords, ropes, performance \\
fabrics, electronic packaging, sports equipment and fiber optics (Hearle, 2001; Kerr, & Chawla and Chawla, 2005). It is well known that the highest tenacity and elastic moduli \\
reported for such fibers are still much lower than their theoretical values. An extensive & open gap between theoretical values and practical results encourage scientists to work \\
and improve the mechanical properties. On the other hand, due to their nonconventional & chemistry and instrumentation, many researches have been concentrated on reducing its \\
production costs. Additionally, there is no single fiber chemistry that can withstand all \\
sort of end-use conditions. The objective of this review paper is to provide a critical and \\
constructive analysis on current state of art high performance fiber production and \\
modification techniques. Current problems and novel solutions were emphasized \\
separately.
\end{tabular}

\section{YÜKSEK PERFORMANSLI LİFLER: GÜNCEL VE GELECEK DURUMU ÜZERİNE} BIR İNCELEME

\begin{tabular}{|c|c|}
\hline Anahtar Kelimeler & Öz \\
\hline $\begin{array}{l}\text { Yüksek performans, lifler, } \\
\text { organik, inorganik, gelecek } \\
\text { beklentileri }\end{array}$ & $\begin{array}{l}\text { Polimerik ve polimerik olmayan liflerin özelliklerinin iyileştirilmesi, örneğin mekanik, } \\
\text { boyutsal stabilite, ısıl bozunma gibi diğer özellikler ile birlikte lif oluşumu sırasında tek } \\
\text { kristal büyümenin katı mekanizması üzerindeki son teorik araştırmaların anlaşılması, lif } \\
\text { karakteristiklerinin alışılmadık üstün özelliklere sahip olmasını sağlar. Benzer șekilde, } \\
\text { yüksek performanslı lifler önemli mühendislik ürünleridir ve boyutsal stabilite ile birlikte } \\
\text { üstün mekanik özelliklerinden dolayı yaygın olarak kullanılırlar. Fiber takviyesi olarak } \\
\text { geniş kullanım alanı bulmuşlardır örneğin kordonlar, halatlar, performans kumaşları, } \\
\text { elektronik ambalajlar, spor malzemeleri ve fiber optikler gibi birçok uygulamada } \\
\text { kullanılabilirler (Hearle, 2001; Kerr, Chawla ve Chawla, 2005). Yapılan araștırmalarda } \\
\text { performans liflerinden elde edilen en yüksek mukavemet ve elastik modüllerin teorik } \\
\text { değerlerinden çok daha düşük olduğu iyi bilinmektedir. Teorik değerler ve pratik } \\
\text { sonuçlar arasındaki açık fark, bilim insanlarını mekanik özelliklerini iyileştirmek için } \\
\text { araştırmalara teşvik etmektedir. Diğer taraftan, konvansiyonel olmayan yöntem ve } \\
\text { kimyasalların bulunmasıla yüksek performans lif üretiminde maliyetlerin düşürülmesi } \\
\text { için birçok araştırma yapılmaktadır. Ek olarak, her türlü son kullanım koșuluna } \\
\text { dayanabilecek tek bir lif kimyası bulunmamaktadır. Bu çalıșmada, son teknolojiye sahip } \\
\text { yüksek performanslı elyaf üretimi ve modifikasyon teknikleri hakkında bir inceleme } \\
\text { yapılmıștır. Güncel sorunlar ve yeni çözümler ayrı ayrı ele alınıp vurgulanmıștır. }\end{array}$ \\
\hline
\end{tabular}

${ }^{*}$ Corresponding author; e-mail: havci@ogu.edu.tr 
Eskişehir Osmangazi Üniversitesi Mühendislik ve Mimarlık Fakültesi Dergisi 27(2), 130 - 155, 2019
Journal of Engineering and Architecture Faculty of

Eskisehir Osmangazi University 27(2), 130-155, 2019

\begin{tabular}{llll}
\hline Review Article & & Derleme Makalesi & \\
Submission Date & $: 09.03 .2019$ & Başvuru Tarihi & $: 09.03 .2019$ \\
Accepted Date & $: 09.07 .2019$ & Kabul Tarihi & $: 09.07 .2019$ \\
\hline
\end{tabular}

\section{Introduction}

Understanding the relation between properties and performances of different high-tech and highperformance fibers to enhance the mechanical property with dimensional stability of structural morphology has been the subject of many research projects during the past few decades. The use of polymers in different fields continues at a dizzying speed (Avci, Guzel, Erol and Akpek, 2018; Calisir, Erol, Kilic and Avci, 2016).

Usually, crystal moduli are determined in the parallel direction, to the polymer chain axis via X-ray diffraction. The theoretical modulus of polypropylene is $35-42 \mathrm{GPa}$ when measured by the X-ray technique with the theoretical strength of $3.9 \mathrm{GPa}$ which is much higher as compared to the maximum tenacity and modulus achieved through any of the existing research laboratory and industrial process (Mukhopadhyay et al., 2004). However, there are some exceptions such as the tensile moduli of highly drawn fibers produced from ultrahigh molecular weight polyethylene (UHMW PE). After the discovery of the Ziegler-Natta catalysts in the 1950s, the linear polyethylene and stereoregular polypropylene became the important industrial polymers. Kevlar also showed the moduli close to the theoretical values (Porter and Wang, 1995; Mazraeh-Shahi and Mojtahedi, 2010). Figure 1 demonstrates that most of the polymers, including those with rigid backbone chains, have much lower tensile moduli of those crystalline lattices in the chain direction.

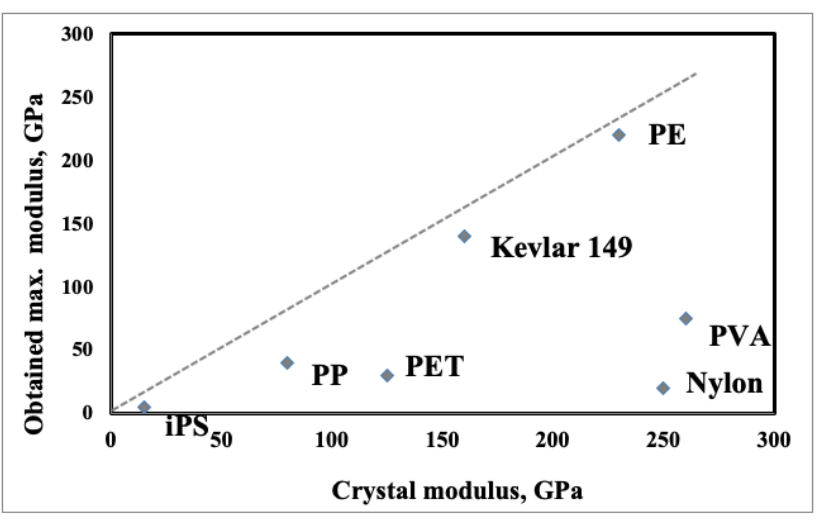

Figure 1. Comparison of The Theoretical Crystalline Lattice Moduli of Polymers with Their Maximum Reported Experimental Fiber Moduli (Porter and Wang, 1995).
In addition to the high-performance polymeric fibers, high performance inorganic fibers are produced by inorganic chemical compounds, such as carbon, silicon, boron and etc., usually after treatment at high temperature. They demonstrate the outstanding features of ultra-high tensile strength and modulus with their resistance to extreme heat and cold in addition to the utilization of several chemical agents, which can degrade polymeric fibers. Therefore, high performance inorganic fibers hold promises not only as a means to compensate for technical applications, but also as a means to improve the standard of material requirements for extreme applications, such as race cars, airplanes' parts, sports equipment for extreme conditions (extreme cold and heat, corrosive environments, bacterial attacks, etc.), and protective clothing.

\section{Historical remarks}

High performance fibers have been an important industrial constituent for many different applications. They have been developed to find an extensive use in the markets as reinforcement fibers and in application where high performances are needed such as cords, ropes, fabrics, load tendons for giant scientific balloons, adhesives and sealants, electronic packaging, sports equipment and fiber optics (Hearle, 2001; Kerr et al., 2005). Table 1 shows some important highperformance fibers and their mechanical properties and applications (Kerr et al., 2005).

High performance fibers are known and defined by their superior characteristics compared to the traditional textile fibers (Figure 3). High performance fibers have high modules, high strength to weight ratio, high chemical and high temperature resistance. 
Eskişehir Osmangazi Üniversitesi Mühendislik ve Mimarlık Fakültesi Dergisi 27(2), 130 - 155, 2019

Table 1

Properties and Applications of High-Performance Fibers (Kerr et al., 2005)

\begin{tabular}{|c|c|c|c|c|}
\hline Fiber & $\begin{array}{l}\text { Young's } \\
\text { modulu } \\
\text { GPA }\end{array}$ & $\begin{array}{l}\text { Tensile } \\
\text { strength } \\
\text { GPA }\end{array}$ & $\begin{array}{l}\text { Diameter } \\
\mu \mathrm{m}\end{array}$ & Applications \\
\hline Steel & 200 & 2.8 & $90-400$ & $\begin{array}{l}\text { Tire cords, } \\
\text { piano wire }\end{array}$ \\
\hline $\begin{array}{l}\text { Ceramic } \\
\left(\mathrm{Al}_{2} \mathrm{O}_{3}-\right. \\
\text { based } \\
\mathrm{SiC}- \\
\text { based) }\end{array}$ & $350-380$ & $1.7-5$ & 42297 & $\begin{array}{l}\text { Ceramic } \\
\text { matrix } \\
\text { composite, } \\
\text { high } \\
\text { temperature } \\
\text { application }\end{array}$ \\
\hline Aramid & $65-130$ & $2.8-3.4$ & 12 & $\begin{array}{l}\text { Body armor, } \\
\text { bullet proof } \\
\text { vest }\end{array}$ \\
\hline Nylon & 6 & 1 & $20-40$ & $\begin{array}{l}\text { Tire cords, } \\
\text { polymer } \\
\text { matrix } \\
\text { composites }\end{array}$ \\
\hline Carbon & $180-600$ & $2.2-3.8$ & 42195 & $\begin{array}{l}\text { Automotive, } \\
\text { aerospace, } \\
\text { sporting } \\
\text { equipment }\end{array}$ \\
\hline $\begin{array}{l}\text { Glass } \\
\text { (silica- } \\
\text { based) }\end{array}$ & 70 & $1.8-3.4$ & 42230 & $\begin{array}{l}\text { Fiber optics, } \\
\text { polymer } \\
\text { matrix } \\
\text { composites }\end{array}$ \\
\hline
\end{tabular}

\subsection{High performance fibers classification}

High performance fiber can be classified according to their chemical structure as follow:

- Aromatic Fibers, this group of fiber are including:

a. Aromatic Polyamides or Aramids: Nomex $\AA$, Kevlar $\AA$ developed by DuPont

b. Aromatic Polyesters: Vectran $\AA$ an aromatic polyester fiber by Celanese Corp

c. Aromatic Polyimides: Polyimide 2080 by Dow Chemical Co.

d. Aromatic Heterocyclic Polymers: Polybenzimidazole ${ }^{\circledR}$ (PBI) by Celanese Corp., Polybenzobisthiazole (PBT) by Celanese and DuPont, while Polybenzobisoxazole (PBO) by Toyobo Co. Ltd

- Polyolefin Fibers: Gel spun polyethylene 'Ultra High Molecular Weight Polyethylene' which has
Journal of Engineering and Architecture Faculty of

Eskisehir Osmangazi University 27(2), 130-155, 2019

to brands, Spectra $\AA$ by Honeywell and Dyneema ${ }^{\circledR}$ by DSM and Toyobo.

- Carbon Fibers: Polyacrylonitrile (PAN) carbon fiber or pitch-based carbon fiber from BASF, Amoco, Ashland and other companies

- Inorganic Fibers: this group are including different kind of fibers such as basalt fibers, boron fibers, silicon carbide fiber, glass fibers (Gupta, 2005)

During the first half of the twentieth century nylon, polyester, acetate, etc. fibers were manufactured with outstanding technical properties and then started to be used widely in automobile tires as reinforcement instead of cotton and rayon (Hearle, 2001). In addition, nylon and polyester fibers have a certain degree of high strength and extension which results a very high energy to break along with good recovery properties. At this point, especially polyester is considered one of the most attractive candidates for high strength fibers that can be used in the ballistic applications and for making highperformance ropes. Structural perfection, such as unfolded, well aligned to the fiber axes, stable, and densely-packed chains and a combination of extended chains with high crystal orientation cause high modulus and strength (Kotek, 2008).

The second-generation of man-made fibers were produced from rigid and flexible polymers during the last half of the twentieth century. These fibers show high performance and are named as high-modulus, hightenacity (HM-HT) fibers with high thermal and chemical resistance (Hearle, 2001). Today, superior strength, stiffness and ballistic performance are considering as a defining characteristic of high-performance polymeric fibers.
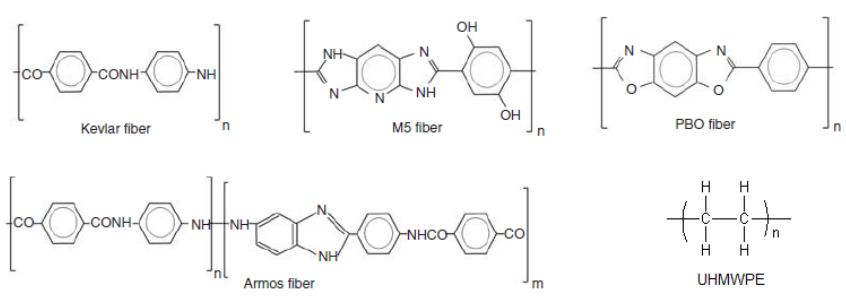

Figure 2. Chemical Structure of High-Performance Organic Fibers. 
Eskişehir Osmangazi Üniversitesi Mühendislik ve Mimarlık Fakültesi Dergisi 27(2), 130 - 155, 2019

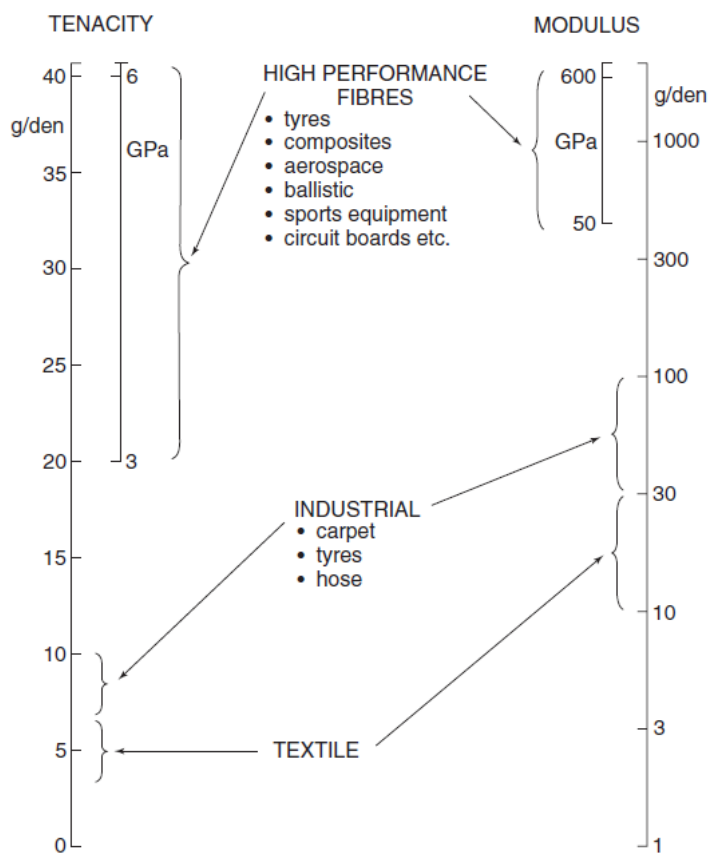

Figure 3. The Change in Strength and Stiffness of Manufactured Fibers (Hearle, 2001).

These fibers, in tension, show rate-independent linear elastic materials and they are durable in transverse compression without a noticed loss in their tensile load capacity even if being exposed to a large plastic deformation (Grujicic, Bell, Arakere, He, Xie, and Cheeseman, 2010). This behavior is a quite different compared to carbon and glass fibers. Kevlar, M5, and PBO have intrinsically rigid chain polymers, but ultrahigh molecular weight polyethylene has a flexible polymer chain.

\section{Chemical Structures of High-Performance Fibers}

\subsection{Aromatic Polyamides}

Aromatic polyamides or Aramid polymers are including both $\mathrm{m}$-aramid and $\mathrm{p}$-aramid polymers. m-aramid means that meta-aramid is linked to meta-positions of the phenylene ring, and p-aramid means that paraaramid is linked to para-positions of the phenylene ring as shown in Figure 4.

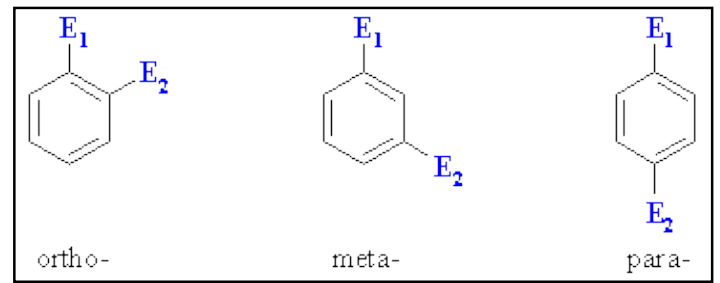

Figure 4. Ortho, Meta and Para Positions ("Substituent Effects", 2019).
Journal of Engineering and Architecture Faculty of Eskisehir Osmangazi University 27(2), 130-155, 2019

\subsection{1. $\operatorname{Kevlar}{ }^{\circledR}$}

Kevlar® one of the most known fiber from the aramid family, it is based on poly (p-phenyleneterephthalamide) (PPTT) polymer. Figure 5 represents the chemical structure of Kevlar@ fiber (Gupta, 2005). Figure 6 shows the monomers and polymerization process that are used to prepare PPTA or Kevlar®.

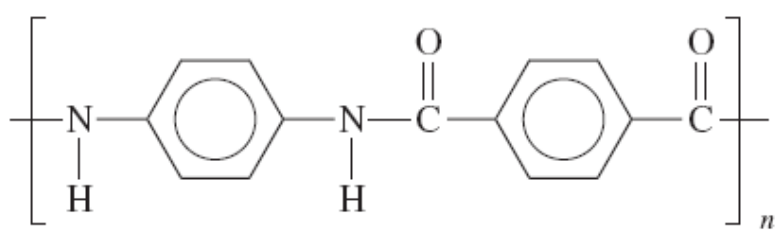

Figure 5. Chemical Structure of Kevlar $\AA$ polymer

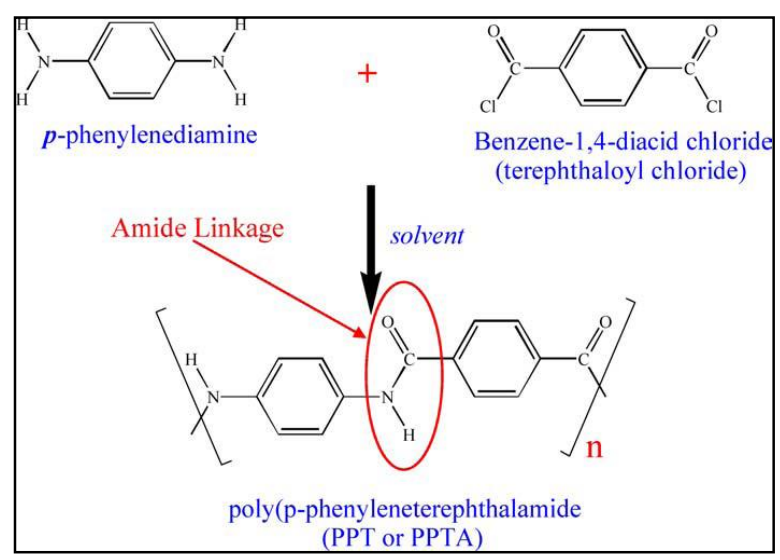

Figure 6. Chemistry of Kevlar or Poly(P-

Phenyleneterephthalamide)

(Holmes, Rice and Snyder, 2006).

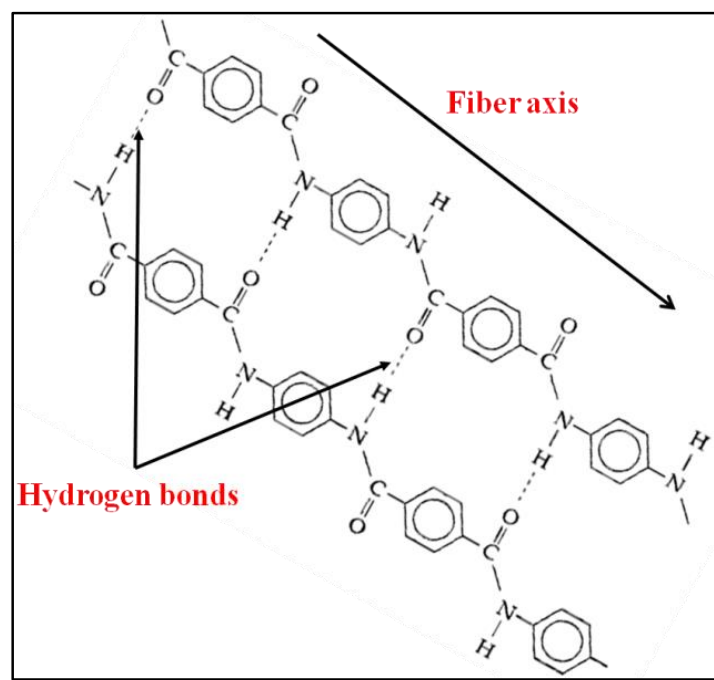

Figure 7. Hydrogen Bonding Between Kevlar Chains in The Crystallite (Penn and Larsen, 1979). 
Eskişehir Osmangazi Üniversitesi Mühendislik ve Mimarlık Fakültesi Dergisi 27(2), 130 - 155, 2019

Figure 7 shows the hydrogen bond between the chains of Kevlar fiber within the crystallite. These hydrogen bonds are tying the polymer molecules together which resulting in increasing the tensile strength.

Table 2

Properties of Different Grads of Kevlar® Fiber (Gupta, 2005).

\begin{tabular}{|c|c|c|c|c|c|}
\hline Grade & $\begin{array}{l}\text { Density } \\
\mathrm{g} / \mathrm{m}^{3}\end{array}$ & $\begin{array}{l}\text { TM } \\
\mathrm{g} / \mathrm{d}\end{array}$ & $\begin{array}{l}\text { TS } \\
\text { g/denier }\end{array}$ & $\begin{array}{l}\text { TE } \\
\% \\
\end{array}$ & MR \% \\
\hline 29 & 1.44 & 488 & 22 & 4 & 7 \\
\hline 49 & 1.44 & 976 & 22 & 2.5 & 4.5 \\
\hline 68 & 1.44 & $\begin{array}{l}715- \\
780\end{array}$ & 24 & 2.9 & 6 \\
\hline 149 & 1.47 & 1100 & 19 & 1.5 & $1-1.2$ \\
\hline
\end{tabular}

*TM: Tensile modulus, TS: Tensile Strength, TE: Tensile Elongation, MR: Moisture Regain

\subsubsection{Nomex®}

Nomex® aramid fiber is based on poly-mphenyleneisophthalamide, which was also commercialized by DuPont in 1967 as aramid fiber. Figure 8 display the chemical structure of Nomex ${ }^{\circledR}$ fiber.

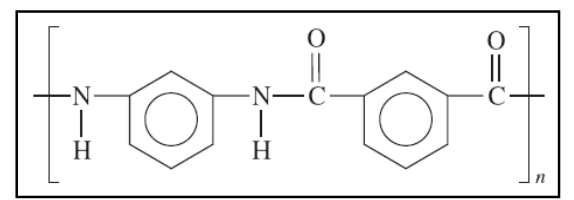

Figure 8. Chemical Structure of Repeat Unit for Nomex® Fiber

The difference between Kevlar and Nomex is that the Kevlar $\AA$ is para-aramid while Nomex $\AA$ is meta-aramid. This small difference in the structure leads to a significant difference in physical and mechanical properties as shown in Table 3. For example, in Kevlar, poly ( $p$-phenyleneterephthalamide), the polymer chains are very stiff and rigid because of phenylene rings and the amide groups are linked in para position. But in Nomex $₫$ fibers, the phenylene ring and amide group are linked in the meta-position, which lead to an irregular chain conformation and a correspondingly lower tensile modulus (Hearle, 2001; Afshari, Sikkema, Lee and Bogle, 2008).
Journal of Engineering and Architecture Faculty of

Eskisehir Osmangazi University 27(2), 130-155, 2019

Table 3

Properties of Different Type of Aramid Fibers (Hearle, 2001).

\begin{tabular}{lllll}
\hline Material & $\begin{array}{l}\text { Density } \\
\left(\mathrm{g} / \mathrm{m}^{3}\right)\end{array}$ & $\begin{array}{l}\text { Decomposi } \\
\text { tion melt } \\
\left({ }^{\circ} \mathrm{C}\right)\end{array}$ & $\begin{array}{l}\text { Tenacity } \\
(\mathrm{mN} / \mathrm{tex})\end{array}$ & $\begin{array}{l}\text { Initial } \\
\text { modulus } \\
(\mathrm{N} / \text { tex })\end{array}$ \\
\hline $\begin{array}{l}\text { Para- } \\
\text { aramid } \\
\text { standard }\end{array}$ & 1.44 & 550 & 2065 & 55.0 \\
Nomex® & 1.46 & 415 & 485 & 7.50 \\
PA 66 & 1.14 & 255 & 830 & 5.00 \\
\hline
\end{tabular}

\subsection{Aromatic Polyesters}

\subsubsection{Vectran ${ }^{\circledR}$}

Vectran $®$ belongs to aromatic polyesters class of highperformance fibers. The chemical structure for this polymer is based on co-polyesters as shown in Figure 9. Mechanical and physical properties of two different types of Vectran ${ }^{\circledR}$ fibers are shown in Table 4.

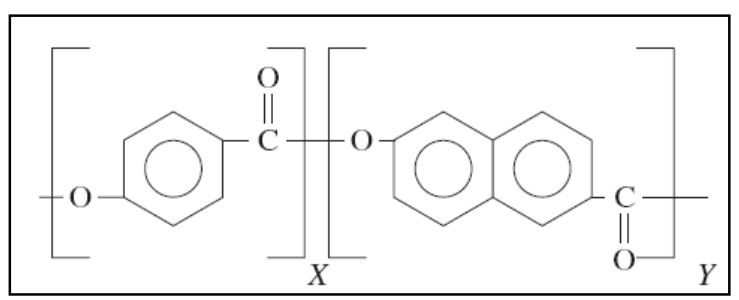

Figure 9. Chemical Structure of Repeat Unit for Vectran (Gupta, 2005).

Table 4

Properties of Vectran fiber (Gupta, 2005).

\begin{tabular}{|c|c|c|}
\hline Properties & Vectran $®$ HS & Vectarn $® M$ \\
\hline $\begin{array}{l}\text { Tensile strength, } \\
\text { g/denier }\end{array}$ & 23 & 9 \\
\hline $\begin{array}{l}\text { Tensile modulus, } \\
\text { g/denier }\end{array}$ & 525 & 425 \\
\hline $\begin{array}{c}\text { Elongation at } \\
\text { break, \% }\end{array}$ & 3.3 & 2 \\
\hline Melting point, ${ }^{\circ} \mathrm{C}$ & 330 & 276 \\
\hline Moisture regain, $\%$ & $<0.1$ & $<0.1$ \\
\hline Density, $\mathrm{g} / \mathrm{cm}^{3}$ & 1.4 & 1.4 \\
\hline $\begin{array}{l}\text { Chemical } \\
\text { resistance }\end{array}$ & \multicolumn{2}{|c|}{$\begin{array}{l}\text { Hydrolytically stable. Resistant to } \\
\text { organic solvent. } \\
\text { Stable to acids }<90 \% \text { conc. Stable to } \\
\text { base }<30 \% \text { conc. } \\
\text { Vectran } ® \text { HS is the high strength } \\
\text { reinforcement fiber } \\
\text { Vectarn } ® \text { M is high performance matrix } \\
\text { fiber }\end{array}$} \\
\hline
\end{tabular}


Eskişehir Osmangazi Üniversitesi Mühendislik ve Mimarlık Fakültesi Dergisi 27(2), 130 - 155, 2019

Figure 10 shows a comparison between Vectran $®$ fiber and other high-performance fiber like Kevlarß. It is obvious that Vectran $\AA$ fibers have excellent creep resistance compared to Kevlar® and UHMWPE fibers (Spectra $\AA$, Dyneema $®$ ), which makes it very suitable for industrial ropes applications. On the other hand, it can be noticed from Figure 11 and 12 that Vectran exhibit a very poor UV resistance.

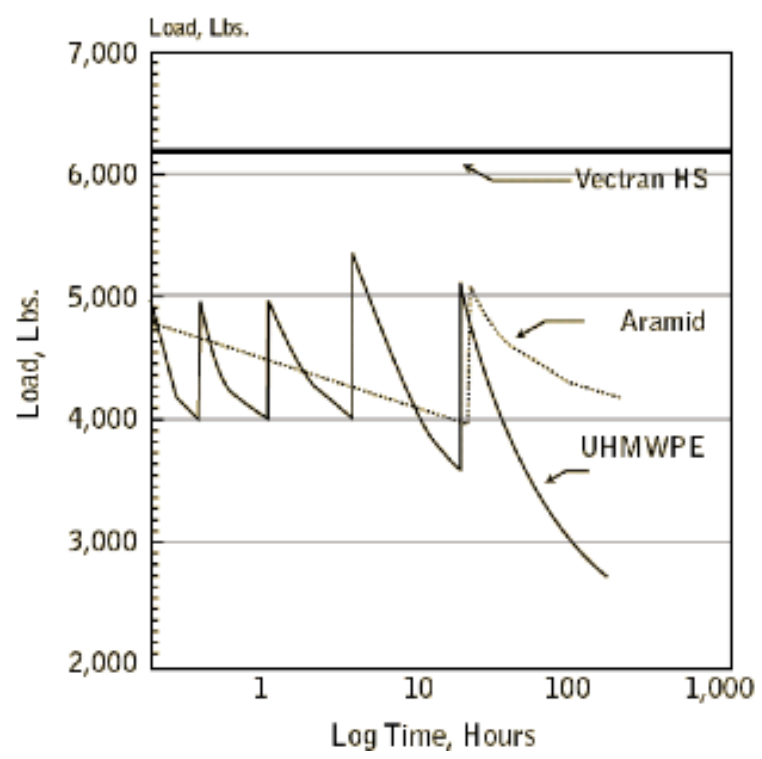

Figure 10. Creep Behavior of Vectran Compared to Other High-Performance Fiber (Fette and Sovinski, 2004).

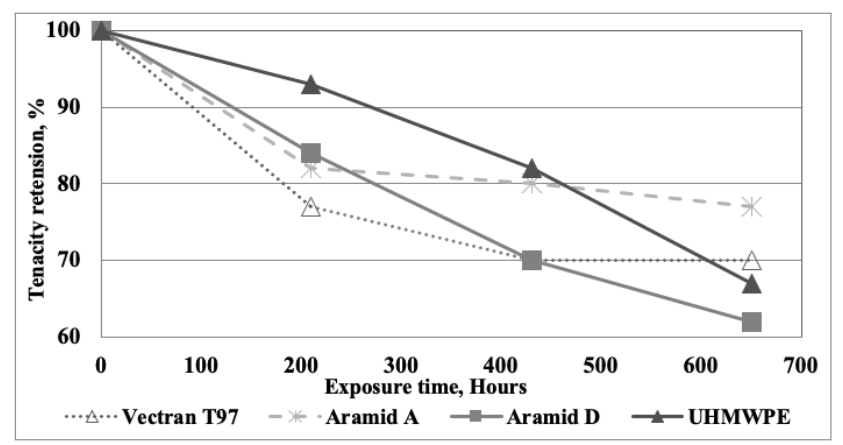

Figure 11. Effect of UV on Tensile Strength of Vectran, Aramid and UHMWPE ("Vectran Fiber", 2019).
Journal of Engineering and Architecture Faculty of Eskisehir Osmangazi University 27(2), 130-155, 2019

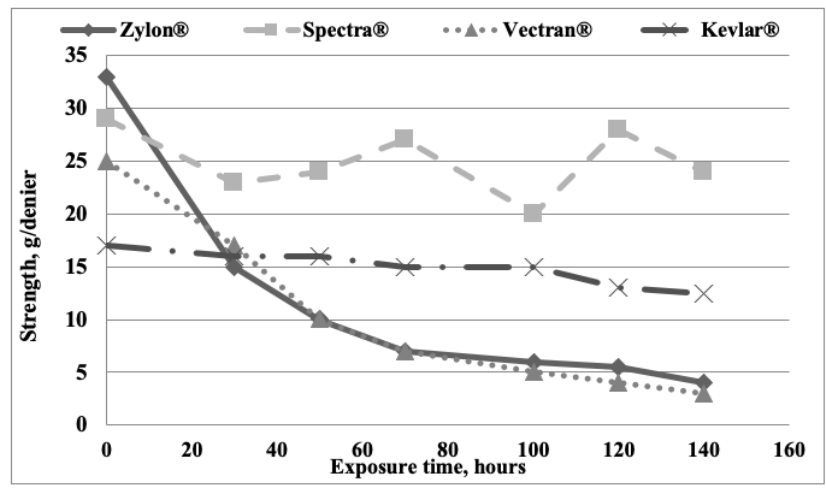

Figure 12. Effect of UV Radiation on Strength of Vectran And Other High-Performance Fibers (Said, Dingwall, Gupta, Seyam, Mock and Theyson, 2006).

\subsection{Aromatic Heterocyclic Polymers}

Heterocyclic polymers are a linear polymer containing a heterocyclic ring, these rings are linked together by one or more covalent bond. Due to this chemical composition, the molecules of these polymers are characterized by high rigidity and form high oriented structure. Different heterocyclic polymers have been developed as shown in Figure 13.

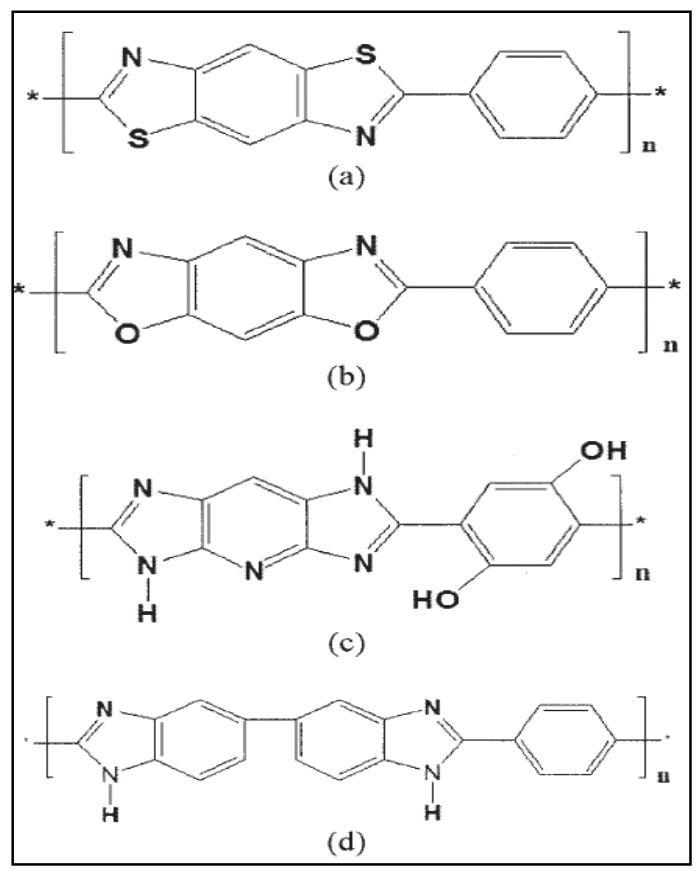

Figure 13. Different Types of Heterocyclic Rigid-Rod like Polymers: (A) Poly ( $P$-Phenylene-2, 6-

Benzobisthiazole) (PBZT), (B) Poly (P-Phenylene-2, 6-

Benzobisoxazole) (PBO, Zylon $®),(C)$ Poly $(2,6-$

Diimidazo(4,5-B:4,5,-E)Pyridinylene-1,4(2,5-

Dihydroxy)Phenylene) (PIPD, M5), (D) Poly (2, 2,-(M-

Phenylene)-5, 5,-Bisbenzimidazole) (PBI) (Chae and Kumar, 2006). 
Eskişehir Osmangazi Üniversitesi Mühendislik ve Mimarlık Fakültesi Dergisi 27(2), 130 - 155, 2019

\subsubsection{Zylon ${ }^{\circledR}$}

Poly-p-phenylenebenzobisoxazole (PBO) belong to the family of liquid crystalline polymers that is orient easily into unfolded or extended chain configurations resulting fibers with excellent mechanical properties (strength and modulus). PBO polymer was developed by the U.S. Air Force to replace traditional heavy metals in space and aviation applications due to its lightweight, excellent thermal stability and chemical resistance (Hearle, 2001). Figure 14 shows the chemical structure of Zylon® fiber.

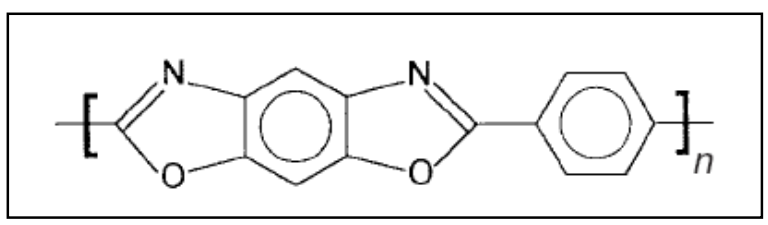

Figure 14. Chemical Structure of Repeat Unit For PBO.

There are two available types of Zylon® fibers, AS (as spun) and HM (high modulus). HM fibers are obtained by post spinning, whereas polymer is treated with heat and drawing. Due to this treatment, HM performance is higher than AS as it can be seen from Table 5 (Bourbigot et al., 2001).

\section{Table 5}

Mechanical and Physical Properties of Zylon® Fiber (Bourbigot, Flambard and Duquesne, 2001).

\begin{tabular}{lccc} 
& & Zylon® AS & Zylon® HM \\
\hline Fiber decitex & & 1.7 & 1.7 \\
Density (g/m3) & & 1.54 & 1.56 \\
Tensile & $\mathrm{cN} /$ dtex & 37 & 37 \\
& $\mathrm{GPa}$ & 5.8 & 5.8 \\
Tensile modulus & $\mathrm{cN} / \mathrm{dtex}$ & 1150 & 1720 \\
& $\mathrm{GPa}$ & 180 & 270 \\
Elongation at break \% & 3.5 & 2.5 \\
Moisture regain \% & 2 & 0.6 \\
Decomposition Temp & 650 & 650 \\
LOI & 68 & 68 \\
Thermal expansion coefficient & - & $(-6)$ X $10-6$
\end{tabular}

There are many applications for Zylon ®fibers:

- Protective clothing: fire fighters suites, safety gloves, heat resistance clothing, etc.

- Aerospace: Balloon, aircraft engine fragment barrier, satellite, etc.
Journal of Engineering and Architecture Faculty of

Eskisehir Osmangazi University 27(2), 130-155, 2019

- Sports: sailcloth, yacht rod, tennis racket, fishing rod, racing suite, etc.

- Industrial materials: heat resistance felt, optical fibers cable, cable cover for welding machine, reinforcement for tire and belts (Bourbigot et al., 2001).

From Table 6, it can be noticed that PBO shows the highest ballistic performance among all currently highperformance fibers.

Table 6.

Theoretical Ballistic Performance of Common Fibers (Holmes et al., 2006).

\begin{tabular}{|c|c|c|c|c|c|}
\hline Fiber & $\begin{array}{l}\text { Density } \\
\text { (Calc.) } \\
(\rho) \\
\left(\mathrm{g} / \mathrm{cm}^{3}\right)\end{array}$ & $\begin{array}{l}\text { Strength } \\
(\sigma) \\
(\mathrm{GPa})\end{array}$ & $\begin{array}{l}\text { Failure } \\
\text { Strain }(\varepsilon) \\
(\%)\end{array}$ & $\begin{array}{l}\text { Modulus } \\
(E) \\
(\mathrm{GPa})\end{array}$ & $\begin{array}{r}\left(U^{*}\right)^{1 / 3} \\
(\mathrm{~m} / \mathrm{s})\end{array}$ \\
\hline PBO (as spun) & $(1.56)$ & 5.20 & 3.10 & 169 & 813 \\
\hline Spectra 1000 & $(0.97)$ & 2.57 & 3.50 & 120 & 801 \\
\hline $\begin{array}{l}600 \text { den. Kevlar } \\
\text { KM2 }\end{array}$ & (1.44) & 3.40 & 3.55 & 82.6 & 682 \\
\hline $\begin{array}{l}850 \text { den. Kevlar } \\
\text { KM2 }\end{array}$ & (1.44) & 3.34 & 3.80 & 73.7 & 681 \\
\hline $\begin{array}{l}840 \text { den. Kevlar } \\
129\end{array}$ & (1.44) & 3.24 & 3.25 & 99.1 & 672 \\
\hline $\begin{array}{l}1500 \text { den. Kevlar } \\
29\end{array}$ & (1.44) & 2.90 & 3.38 & 74.4 & 625 \\
\hline $\begin{array}{l}200 \text { den. Kevlar } \\
29\end{array}$ & $(1.44)$ & 2.97 & 2.95 & 91.1 & 624 \\
\hline $\begin{array}{l}1000 \text { den. Kevlar } \\
29\end{array}$ & $(1.44)$ & 2.87 & 3.25 & 78.8 & 621 \\
\hline $\begin{array}{l}1140 \text { den. Kevlar } \\
49\end{array}$ & $(0.91)$ & 3.04 & 1.20 & 120 & 612 \\
\hline Carbon fiber & $(1.80)$ & 3.80 & 1.76 & 227 & 593 \\
\hline E-glass fiber & $(2.89)$ & 3500 & 4.70 & 74 & 559 \\
\hline Nylon & & 0.91 & N/A & 9.57 & 482 \\
\hline $\begin{array}{l}\text { M5 (2001 } \\
\text { Sample) }\end{array}$ & (1.74) & 3.96 & 1.40 & 271 & 583 \\
\hline M5 Conservative & $(1.70)$ & 8.50 & 2.50 & 300 & 940 \\
\hline M5 Goal & $(1.70)$ & 9.50 & 2.50 & 450 & 1043 \\
\hline
\end{tabular}

In Table 6, $\left(\boldsymbol{U}^{*}\right)^{1 / 3}$ is a normalized velocity that allows the relative comparison of fibers independent of the vest construction parameter (Holmes et al., 2006). The higher the value of $\left(U^{*}\right)^{1 / 3}$ is, the higher the ballistic resistance of the fiber.

While PBO fibers possess impressive tensile strength and modulus, unfortunately its performance under compression has been disappointing. Many trials have been done in various ways to overcome this drawback. Various methods have been conducted to improve lateral strength of PBO after fiber formation, often by cross-linking. The lack of success in improving compression properties was attributed to the hydrogen bonds being formed intra- rather than inter-molecularly (Hearle, 2001).

Figures 15 and 16 show a comparison between mechanical and thermal properties of PBO and other fibers. It is very clearly from Figure 15 that Zylon $®$ has 
Eskişehir Osmangazi Üniversitesi Mühendislik ve Mimarlık Fakültesi Dergisi 27(2), 130 - 155, 2019

the highest modulus among the other high-performance fibers. In addition, Zylon® shows the highest thermal stability among the other fibers as shown in Figure 16.

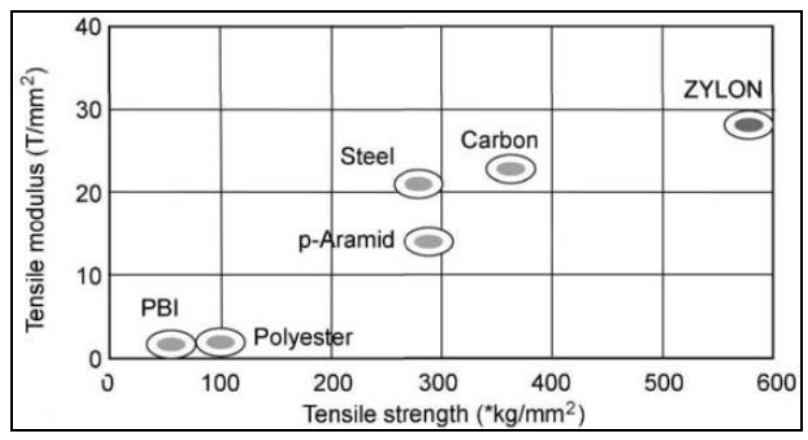

Figure 15. Mechanical properties of Zylon $®$ and Other High-Performance Fibers (Hearle, 2001).

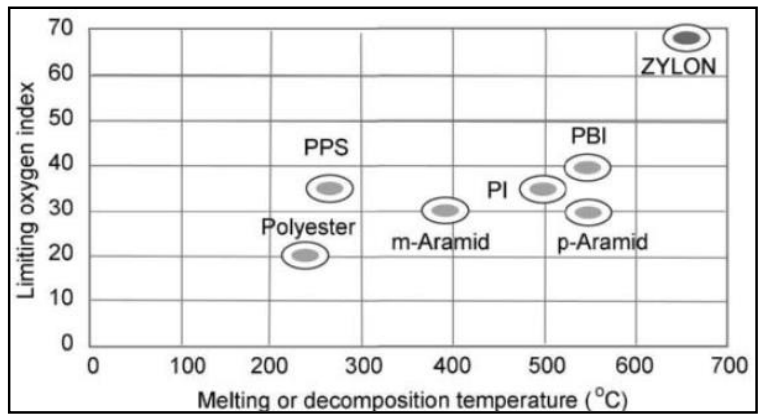

Figure 16. Flame Resistance of Zylon $₫$ and Other HighPerformance Fibers (Hearle, 2001).

Figure 17 shows the effect UV-Visible light exposure on four different types of high-performance fibers. It is obvious that Zylon® losses a significant amount of its strength in a short period of time.

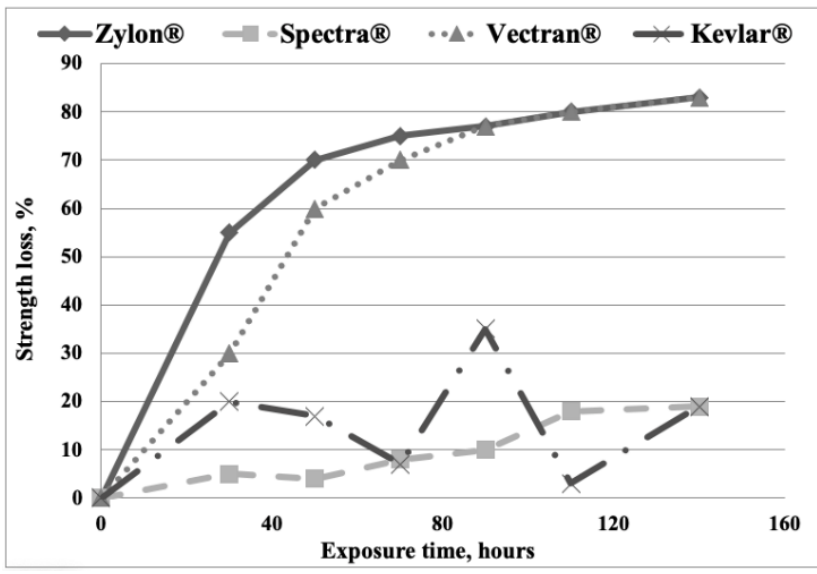

Figure 17. Strength Loss \% in Zylon $®$ and Other HighPerformance Fibers Due to UV Exposure

(Said et al., 2006).
Journal of Engineering and Architecture Faculty of Eskisehir Osmangazi University 27(2), 130-155, 2019

Figure 18 shows the thermal gravimetric analysis of PBO (Zylon) and PPT (Kevlar) under two different environment condition (nitrogen and air). TGA curves show that PBO (Zylon $囚$ ) fibers have better thermal resistance than PPT (Kevlar ${ }^{\circledR}$ ) fibers. It can be noticed that the presence of Oxygen accelerates the degradation process for both fibers PBO and PPT.

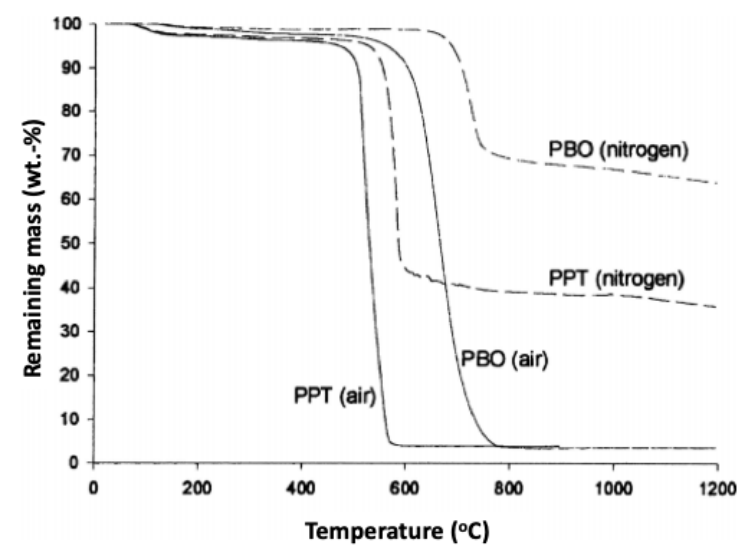

Figure 18. Thermal degradation of PPT and PBO Fibers, Under Nitrogen (Dashed Lines) and Air (solid Lines)

(Bourbigot et al., 2001).

A vest from $\mathrm{PBO}$ fiber was exposed to $50{ }^{\circ} \mathrm{C}$ and $60 \% \mathrm{RH}$ in an environmental dark room for 85 days and then 60 ${ }^{\circ} \mathrm{C}$ and $36 \% \mathrm{RH}$ for an additional 73 days (Cunniff, Auerbach, Vetter and Sikkema, 2002). PBO yarns were unraveled from the back panel of the vest and were tested to assess their degradability. Reduction of $25 \%$ and $36 \%$ in tensile strength of PBO yarn after 85 and 158 days respectively was observed.

\subsubsection{PIPD or 'M5' Rigid-Rod Polymer}

A new high-performance fiber, known as M5®, has been developed as a result of research in Akzo-Nobel laboratories and currently produced by Magellan System International. The polymer is poly\{2,6diimidazo[4,5-b:4',5'-e] pyridinylene-1,4-(2,5ihydroxy)phenylene $\}$ or PIPD. Figure 19a shows the repeat unit of M5 $\AA$ while Figure $19 \mathrm{~b}$ displays the crystal structure of the $M 5 \AA$ fibers.

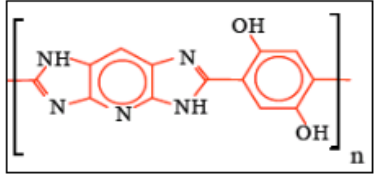

(a)

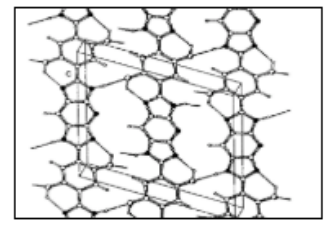

(b)
Figure 19. Chemical Structure of Repeat Unit for M5 Fiber ("Honeywell Advanced Fibers and Composites", 2019). 
Eskişehir Osmangazi Üniversitesi Mühendislik ve Mimarlık Fakültesi Dergisi 27(2), 130 - 155, 2019

The crystal structure of M5 ${ }^{\circledR}$ is different from all other high strength fibers. All other high strength fibers have covalent bonding in the main chain direction, but in case of $M 5^{\circledR}$, as shown in Figure $19 \mathrm{~b}$, there is a hydrogenbond network in the lateral dimensions ("Honeywell Advanced Fibers and Composites", 2019).

Figure 20 shows the effect of heat treatment on the crystal structure of PIPD (M5). During heat treatment of PIPD (M5) fiber, the chains orientation is improved and changing in crystal structure is occurred. The heattreated fiber results in forming a bidirectional hydrogen bonded network, which leads to a strong interaction between polymer chains and results in a high shear and compression strength (Afshari, Sikkema, Lee and Bogle, 2008). As it is shown in Table 7, M5® has a high compressive strength compare to the other highperformance fibers due to a hydrogen-bond in the lateral dimensions.

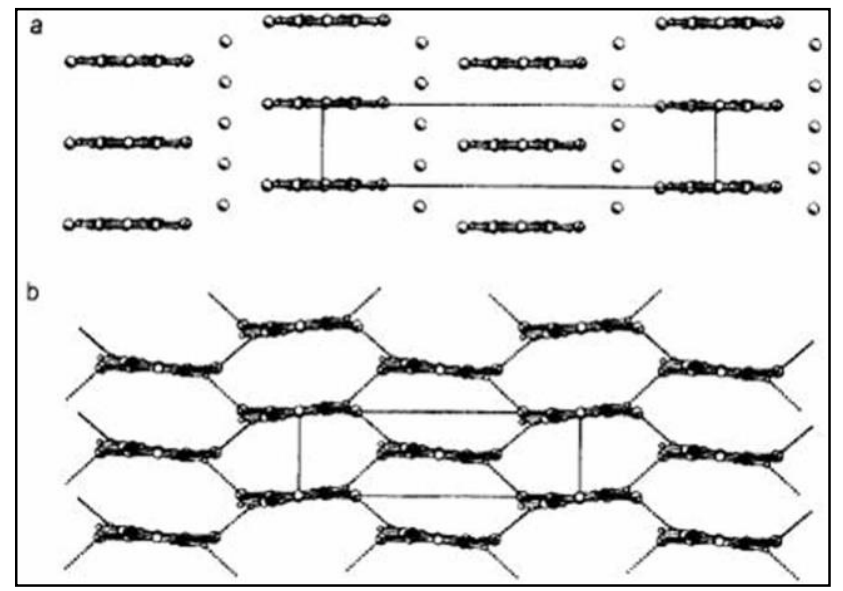

Figure 20. Projection of (a) As-Spun PIPD (M5 $\left.{ }^{\circledR}\right)$ Fiber and (b) Heat-Treated PIPD (M5 $\left.{ }^{\circledR}\right)$ Fiber

(Afshari et al., 2008).

Table 7

Mechanical Properties for Some of High-Performance Fibers (Hearle, 2001).

\begin{tabular}{lllll}
\hline Fiber & $\begin{array}{l}\text { Density } \\
\text { g/cm }\end{array}$ & $\begin{array}{l}\text { TM } \\
\text { GPa }\end{array}$ & $\begin{array}{l}\text { TS } \\
\text { GPa }\end{array}$ & $\begin{array}{l}\text { CS } \\
\text { GPa }\end{array}$ \\
\hline PB0 & 1.56 & 280 & 5.8 & 0.20 \\
PBT & 1.58 & 325 & 4.1 & $0.26-0.41$ \\
M5 & 1.70 & 330 & 4.0 & 1.00 \\
Kevlar 49 & 1.45 & 125 & 3.5 & $0.35-0.45$ \\
Twaron HM & 1.45 & 115 & 3.2 & 0.45 \\
P100 & 2.15 & 725 & 2.2 & 0.48 \\
T 300 & 1.80 & 230 & 3.2 & $2.70-3.20$ \\
Alumina & 3.70 & 350 & 1.7 & 6.90 \\
E-glass & 2.58 & 76 & 3.4 & 4.20 \\
\hline
\end{tabular}

*TM: Tensile modulus, TS: Tensile Strength, CS: Compressive Strength
Journal of Engineering and Architecture Faculty of Eskisehir Osmangazi University 27(2), 130-155, 2019

\subsection{Polyolefin Fibers}

Recently, there is a substantial demand for polyolefin fibers which are found a number of applications particularly in our daily lives and in a wide range of technical fields including electrical materials, medical, transportation, geotextile, sports and so on for demonstrating exceptional performance, excellent chemical resistance, reasonable thermal stability with having low production cost.

Polyolefin fibers can be defined as a polymer that is formed of long-chains via chain growth polymerization composed of at least $85 \%$ by weight of olefins (alkenes) such as ethylene, propylene, or other olefin units. In fact, the dominant products for polyolefin fibers are especially high-density polyethylene (HDPE) and polypropylene, which the second most important plastic, that are a highly versatile and demanded type for the broad range of the materials is estimated $\$ 70$ and 145 billion in 2019, respectively, in the world market ("Market Study: Polyethylene", 2019)

Ultra-High Molecular Weight Polyethylene (UHMPE) or High-Performance Polyethylene (HPPE) fibers are high strength, high modulus based on the simple and flexible polyethylene molecules. These fibers are chemically identical to the normal PE with some differences in their chemical structure such as they comprise very long chains, high chain orientation, and high crystallinity as it is shown in Figure 21.

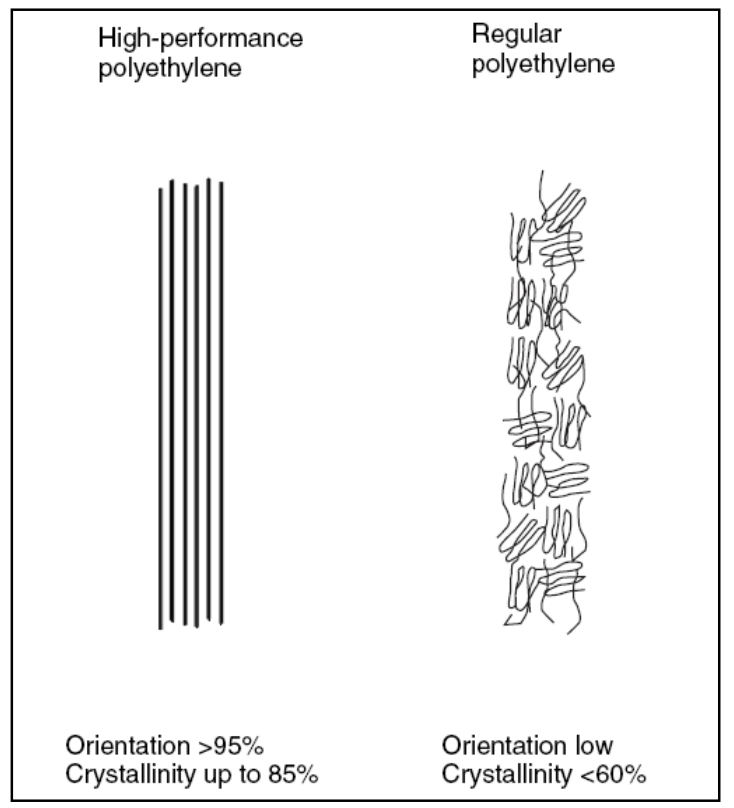

Figure 21. Macromolecular Orientation of HPPE and Normal PE (Gupta, 2005). 
Eskişehir Osmangazi Üniversitesi Mühendislik ve Mimarlık Fakültesi Dergisi 27(2), 130 - 155, 2019

Currently, high performance polyethylene fibers (HHPE) are commercially produced under two trade names, Dyneema ${ }^{\circledR}$ by DSM High Performance Fibers in Netherlands and by Toyobo/DSM joint venture in Japan. The other brand is Spectra ${ }^{\circledR}$ which produced by Honeywell (formerly Allied Signal or Allied Fibers) in the USA.

Now UHMWPE by its both brands Spectra or Dyneema are used in many applications such as:

- Ballistic protection: bullet proof vests, rigid body armor plates, high performance helmet, armor vehicles

- Ropes and cordage: The high strength/weigh ratio of HPPE fibers makes it possible to produce heavyduty ropes with very special characteristics, which make these ropes suitable for many fields like industrial applications, marine, offshore and recreational applications ("Dyneema", 2019).
Journal of Engineering and Architecture Faculty of Eskisehir Osmangazi University 27(2), 130-155, 2019
- Medical applications: Orthopedic and spinal medical devices, cardiovascular applications (Reneker and Mazur, 1983).

- Other applications: cut protection, fishing lines, hurricanes protection (hurricane-resistant storm curtains), etc. ("Dyneema", 2019; Reneker and Mazur 1983).

Table 8 shows the mechanical properties of different types of UHMWPE which are produced by different manufacturers.

Table 8 .

Mechanical Properties of Different Types of UHMWPE (Hearle, 2001).

\begin{tabular}{|c|c|c|c|c|c|}
\hline Materials & Density $\left(\mathrm{g} / \mathrm{cm}^{3}\right)$ & Denier/filament (dpf) & Tenacity (N/tex) & Modulus (N/tex) & Elongation to break (\%) \\
\hline \multicolumn{6}{|l|}{ Honeywell } \\
\hline Spectra 900 & 0.97 & 10 & 2.60 & 75.00 & 3.6 \\
\hline Spectra 1000 & 0.97 & 5 & 3.35 & 110.00 & 3.3 \\
\hline Spectra 2000 & 0.97 & 3.5 & 3.44 & 120.84 & 2.9 \\
\hline \multicolumn{6}{|l|}{ DSM } \\
\hline Dyneema SK60 & 0.97 & 1 & 2.8 & 91 & 3.5 \\
\hline Dyneema SK65 & 0.97 & 1 & 3.1 & 97 & 3.6 \\
\hline Dyneema SK75 & 0.97 & 2 & 3.5 & 112 & 3.8 \\
\hline Dyneema SK76 & 0.97 & 2 & 3.7 & 120 & 3.8 \\
\hline \multicolumn{6}{|l|}{ Toyobo } \\
\hline Dyneema SK60 & 0.97 & 1 & 2.8 & 91 & 3.5 \\
\hline Dyneema SK71 & 0.97 & 1 & 3.5 & 122 & 3.7 \\
\hline
\end{tabular}

The main drawback in HMPE fiber is the low creep resistance. It has been described by Reneker and Mazur that crystal defects is allowing polyethylene molecules to move pass one another (Reneker and Mazur, 1983). When HMPE fibers are used for applications where these fibers will be loaded with high load for a long time, creep rupture has to be taken into considerations especially with high temperature. It has been found that Spectra ${ }^{\circledR} 900$ was crept $13 \%$ under breaking load of $15 \%$ between 10 and 100 days. On the other hand, the creep of Dyneema ${ }^{\circledR}$ SK60 and Spectra ${ }^{\circledR} 1000$ were 6.3 and $0.47 \%$ respectively under $30 \%$ of the breaking load. Results also showed that after 4 days, Spectra ${ }^{\circledR} 900$ was broken, while Spectra ${ }^{\circledR} 1000$ and Dyneema ${ }^{\circledR}$ were survived till 28 days and 123 days respectively. Creep resistance for different brands of UHMWPE and the effect of load are illustrated in Figures 22-24 (Hearle, 2001). Creep resistance for different brands of UHMWPE and the effect of load are illustrated in Figures 22-24. 
Eskişehir Osmangazi Üniversitesi Mühendislik ve Mimarlık Fakültesi Dergisi 27(2), 130 - 155, 2019

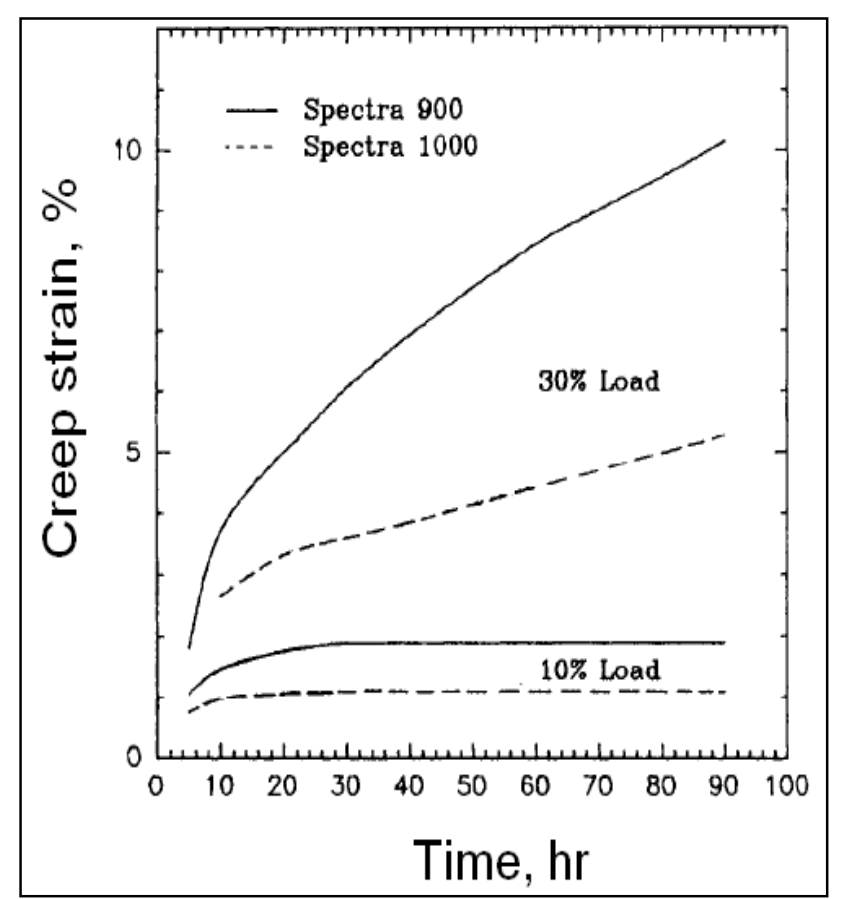

Figure 22. Spectra Extended Chain Creep of Polyethylene Fibers under Room Temperature and Static Ultimate Load of $10 \%$ and $30 \%$ (Penn and Larsen, 1979).

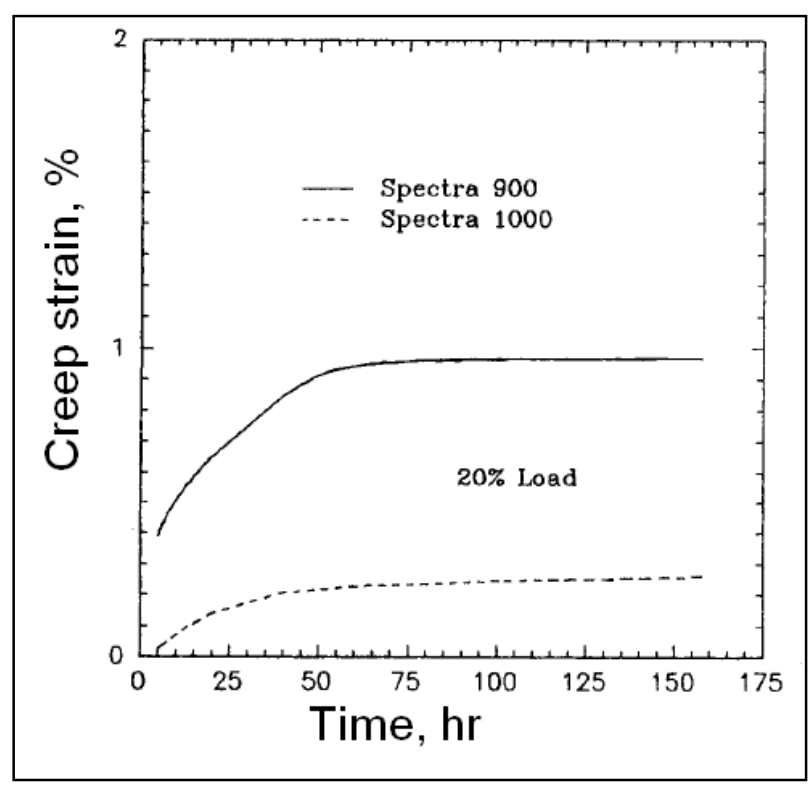

Figure 23. Spectra ${ }^{\circledR}$ Extended Chain Creep of Polyethylene Fibers at 5 degree and Static Ultimate Load of 20\% (Penn and Larsen, 1979).
Journal of Engineering and Architecture Faculty of Eskisehir Osmangazi University 27(2), 130-155, 2019

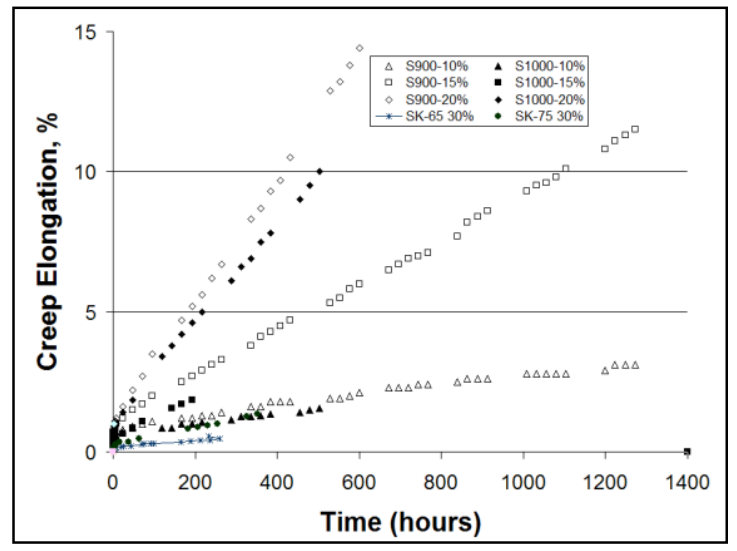

Figure 24. Creep Behavior for Different Brands of UHMWPE ("Ultraviolet radiation and health", 2019)

$$
\begin{aligned}
& \text { S900- Spectra } \AA 900 \\
& \text { S100- Spectra }(100
\end{aligned}
$$

\section{SK-65 And SK-75 For Dyneema®}

Figures 25-29 show comparison in mechanical and chemical properties between HPPE and other highperformance fibers. It is obvious that HPPE fiber have superior mechanical and physical properties such as high modulus and tensile strength, chemical and UV resistance with abrasion resistance compared to the other high-performance fibers. In addition, recently, a novel technique to control formation of the crystal cleavage for LLDPE resulted to obtain ultra-high performance with tunable properties (Seyhan, Tepekiran, Polat, Kilic,, Demir and Avci, 2019).

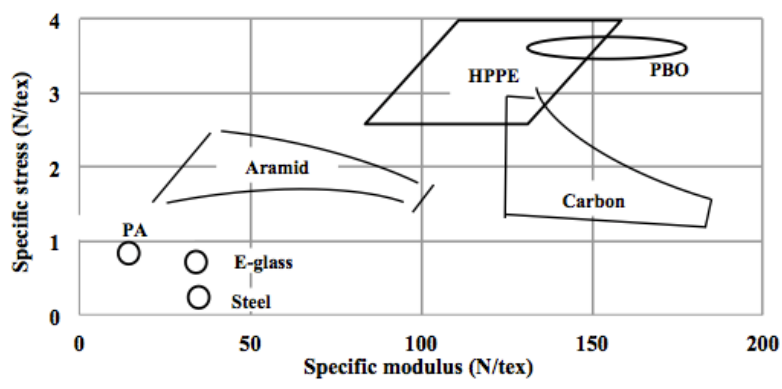

Figure 25. Specific Strength vs Specific Modulus for Different High-Performance Fibers (Hearle, 2001). 
Eskişehir Osmangazi Üniversitesi Mühendislik ve Mimarlık Fakültesi Dergisi 27(2), 130 - 155, 2019

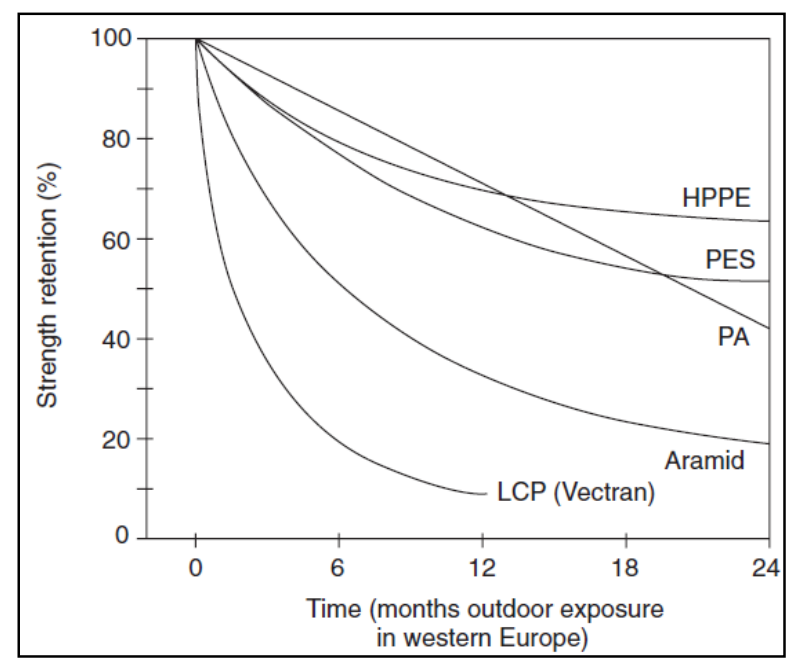

Figure 26. Stress - Strain Curves for Various HighPerformance Fibers (Hearle, 2001).

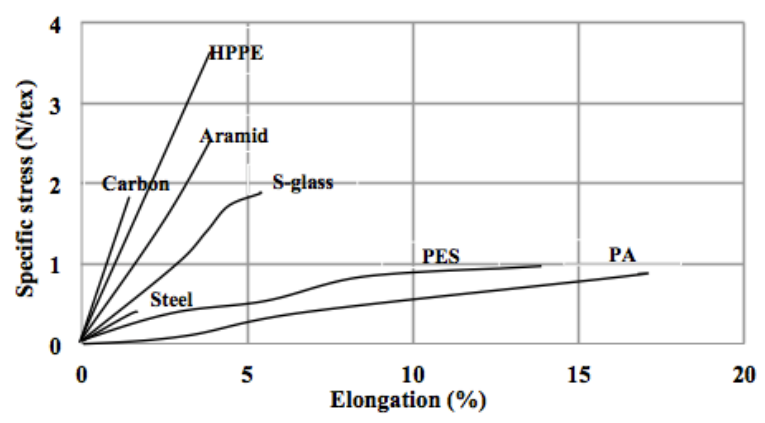

Figure 27. UV Resistance of Various High-Performance Fibers (Hearle, 2001).

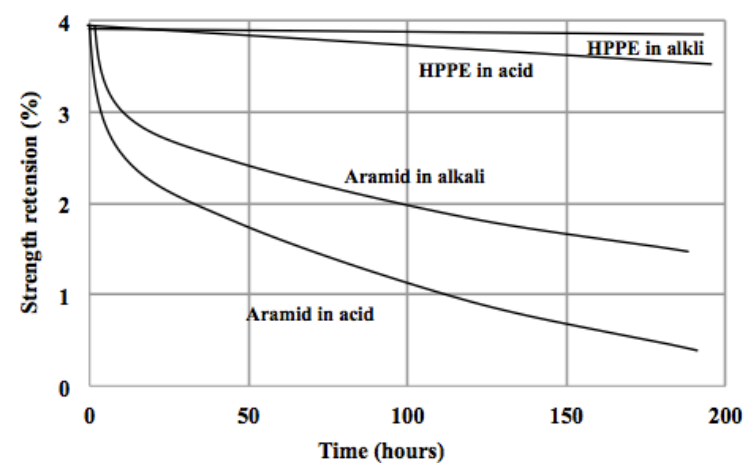

Figure 28. to Acids and Alkalis Resistance: HHPE vs Aramid (Hearle, 2001).
Journal of Engineering and Architecture Faculty of Eskisehir Osmangazi University 27(2), 130-155, 2019

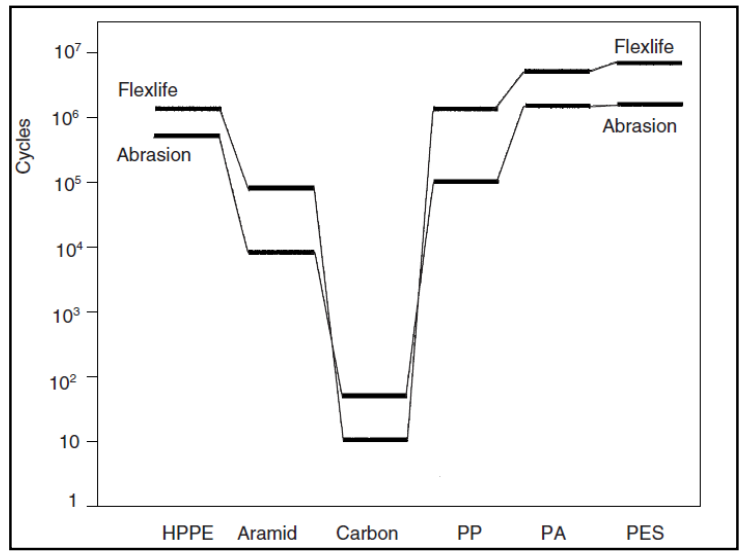

Figure 29. Various Fibers' Abrasion and Flex Life (Hearle, 2001).

Polypropylene (PP) is another member of the polyolefin class of polymers, which has the second largest sales volume in the world. After the first commercial production of PP in 1957 by using Ziegler-Natta catalysts, the world has seen a tremendous increase in the global market for his new type of polymer due to fact that a relatively low melting point of HDPE (Ugbolue, 2009). In general, PP fibers have low cost, exhibit acceptable mechanical properties, high chemical resistance, and moderate thermal stability. In addition, the physical properties of PP can be tailored to meet the requirements with respect to processing and structure. Hence, a large variety of products, such as and not limited to ropes, nets, circular woven bags, many types of tents, different GSM nonwoven fabrics, and reinforcing materials for various composites, medical care and building

Molecular design and morphological features are two crucial parameters to achieve the desired properties. Depending on the molecular design, which is associated with changing the average length of the molecular chains, can affect regularity of packing, and the chain stiffness. Linear chains can be highly oriented, which may lead to a yield a higher degree of crystallinity and a unique microstructure. The stereoregular placement of pendant methyl groups in isotactic-PP causes the facile packing and crystallization, however the atactic PP chains with their stereoregular distribution of methyl substituents, cannot pack tightly and crystallize so atactic-PP is an amorphous polymer. Therefore, the polymer properties itself and external process conditions such as molecular weight, extrusion technique and types, polydispersity, temperature and velocity of extrusion, air flow rate, take-up velocity, etc are very crucial in order to obtain high performance fibers. In general, high degree of entanglement for the polymers and high molecular weight with narrow molecular weight distribution are critical factors to 
Eskişehir Osmangazi Üniversitesi Mühendislik ve Mimarlık Fakültesi Dergisi 27(2), 130 - 155, 2019

obtain high elongational viscosity and degree of crystallinity with high strength and modulus (Mukhopadhyay, Deopura and Alagirusamy, 2004; Porter and Wang, 1995).

Spinning conditions are the important parameters to be controlled in order to produce high-tenacity, highmodulus polypropylene fibers. Sheehan and Cole, (1964) have produced high-tenacity PP filaments with the melt spinning technique by using highly isotactic polypropylene resin with rapid quenching using water to obtain undrawn paracrystalline structure. In this case, they have achieved more than fiber performance of $13 \mathrm{~g} / \mathrm{d}$ after a very high draw ratio of $34 \mathrm{x}$ were applied. It is argued that increasing the draw ratio increases the fraction of taut tie molecules that results in an increase in the orientation of the amorphous chains to support fiber tenacity and modulus (Yamada, Kamezawa and Takayanagi, 1981).

As it is pointed out that drawing process conditions which depend upon polymer molecular weight distribution, molecular weight, morphology, temperature of drawing and strain rate like take-up speed and draw ratio (Mukhopadhyay et al., 2004; Yamada et al., 1981) have a strong influence in increasing the orientation within the amorphous regions and also affect the crystallinity percentage. During the drawing process of a very high draw ratio the spherulite deformation occurs depended on the applied load and this deformation is divided in two main stages. During the first one, lamellar slippage leading to $c$-axis orientation until obtaining fully oriented structure. Once this point is reached, a new type of deformation mechanism is caused by the additional extension, which called crystal cleavage. At this point any further extension leads separation of lamellae in blocks and the helical chain axis of the noncrystalline molecules become more oriented to evolve into a fibrillar structure (Samuels, 1968). Any more deformation after this point causes to develop flaws and the fiber breaks. Taylor and Clark (1978) manufactured 'superdrawn' PP filaments in 2-steps, discontinuous process at elevated temperatures. They used polypropylene with averaged molecular weight of $2.77 \times 10^{5}$ with the drawing rates were varied from $10 \mathrm{~mm} / \mathrm{min}$ to $1 \mathrm{~mm} / \mathrm{min}$ to obtain a high draw ratio of more than $25 \mathrm{x}$ by two-stage of tensile drawing. They concluded the optimum draw temperature of $130{ }^{\circ} \mathrm{C}$ at which a linear relationship between the mechanical properties and the draw ratio was observed. The optimum mechanical properties of $216 \mathrm{~g} / \mathrm{d}$ for the tensile modulus and $9 \mathrm{~g} / \mathrm{d}$ for tensile strength were achieved with elongation at break of 7.8 $\%$. The presented morphology of the 'superdrawn' fiber was the substantial increase in the amount number of tie molecules at the optimum temperature of $130{ }^{\circ} \mathrm{C}$. Additional tie molecules were formed by unfolding of chains that were important parameters to explain this
Journal of Engineering and Architecture Faculty of Eskisehir Osmangazi University 27(2), 130-155, 2019

concept. In addition, sliding displacement of microfibrils is another mechanism to control the fluid flow behavior for drawing ratio.

Cansfield, Capaccio and Ward (1976) and De Candia, Romano, Baranov and Prut (1992) have also investigate the drawing of $i$-PP fibers at high temperature by twostage isothermal drawing process. They concluded there was no any good improvement for the structure while any further drawing after a saturation value, and lower drawing temperatures below $80{ }^{\circ} \mathrm{C}$, do not have any effect to improve the mechanical properties.

Zone drawing with zone annealing is another promising method in which a component with higher temperature is able to localize a part of spun fibers during the drawing process (Mukhopadhyay et al., 2004; Ohta, 1983). In addition, Kunugi, Ito, Hashimoto and Ooishi, (1983) have studied the zone-annealing method, which consists of two zone drawing stages (1- highly oriented amorphous filament), and zone annealing (2-highly oriented crystalline fibers) as seen in Figure 30.

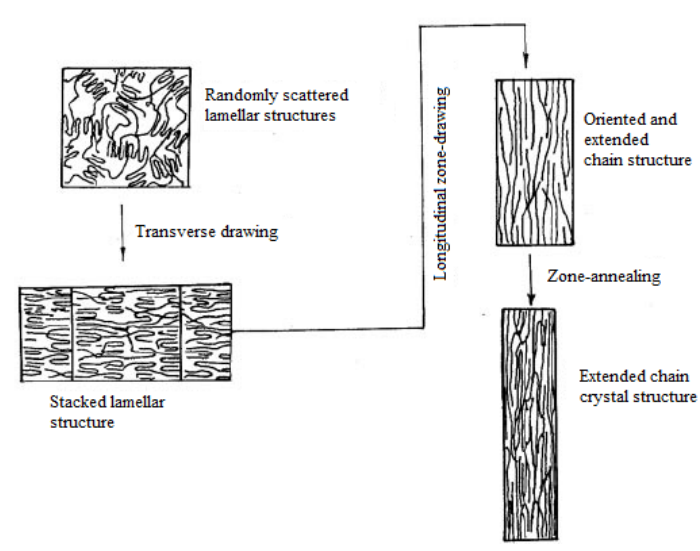

Figure 30. The Change in Structure During ZoneDrawing and Zone-Annealing. (Reprinted with permission Copyright John Wiley and Sons, 2003, Sheehan and Cole, 1964).

Sheehan and Cole (1964) manufactured 'super-tenacity' polypropylene filaments by a monofilament spinneret with drawing and annealing processes. Fibers were quenched with air, water bath and/or continuous drawing machine via a heated glycerine bath. Furthermore, a convection oven with a fixed load was used to draw the monofilaments under constant tension. The oven temperature was gradually increased to 130 $135{ }^{\circ} \mathrm{C}$, and then the drawing was performed under same tension at elevated temperature to obtain the final drawing ratio. Lastly, the fibers were allowed to cool down to room temperature and then the weight was removed. In this process, the fibers were not annealed. The maximum tenacity was observed at $34 \mathrm{x}$ draw ratios 
Eskişehir Osmangazi Üniversitesi Mühendislik ve Mimarlık Fakültesi Dergisi 27(2), 130 - 155, 2019

which value is $13.1 \mathrm{~g} / \mathrm{d}$ and the tensile modulus value was $110 \mathrm{~g} / \mathrm{d}$.

Another type of attempt is die-drawing that has been explored as means of producing filaments or rods by drawing polymers through a conical die. In this case, researchers have tried to make an alternative technique instead of solvents-based melt spinning and drawing under special conditions to produce high performance materials. Figure 31 explains the principle of diedrawing that the solid polymer is moved by conducting a pulling force at the exit side of the converging die to steady drawing of the polymer through the die at some diameters (Mukhopadhyay et al., 2004; Coates and Ward, 1979). Ultra-oriented polyolefin rod was achieved with tensile modulus of 20.6 GPa (Coates and Ward, 1979). The researchers suggested to develop it into a continuous process because of the equipment design is relatively simple when compared to traditional extrusion process. Shaw (1975) has pointed out the die design with using effective external lubricants, which prevented the distortion problems for the products and controlled axial extension rates. Hot nip drawing (Laughner and Harrison 1988) has also the similar working principles to manufacture higher Young's modulus and tensile strength.

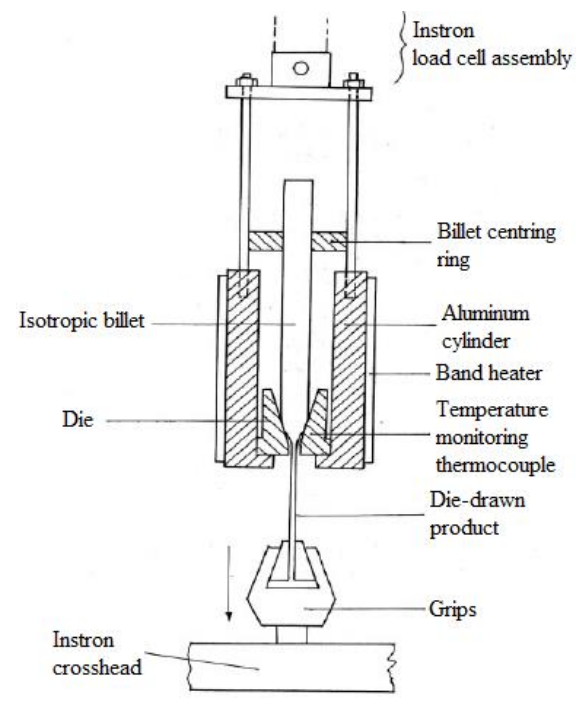

Figure 31. A Small Representation of Die Drawing (Mukhopadhyay et al., 2004).

Almost all these techniques require some special equipment and their production rates are low. Therefore, the most of these methods were not to applied for industrial scale and application. A promising method to decrease production cost and enhance mechanical properties of PET fibers, in the 1990s, (Cuculo, Tucker, Chen and Lundberg, 1993; Cuculo, Tucker, Lundberg, Chen, $\mathrm{Wu}$ and Chen, 1998). investigated a new melt-spinning process with the
Journal of Engineering and Architecture Faculty of Eskisehir Osmangazi University 27(2), 130-155, 2019

liquid isothermal bath (LIB) was to manufacture high performance PET fibers After the bath modification, a novel horizontal liquid isothermal bath (hIB) (for the detailed information see the chapter 4.3) has been developed to not use only for laboratory scale work but also in the industry because of the feasibility, less capital equipment and energy sources. Finally, Avci et al. (Avci, Kotek and Yoon, 2013; Avci, Kotek and Toliver, 2015; Avci, Kotek and Yoon, 2013; Najafi, Avci and Kotek 2015; Yoon, Avci, Najafi, Nasri, Hudson and Kotek 2017) have developed cost-efficient an environmentally friendly isothermal bath for the production a new type of ultrahigh-performance polyolefin and other thermoplastic fibers at relatively high throughputs. A new and unique high oriented precursor $\left(f_{\mathrm{a}}=0.60\right)$ (Figure 33), and noncrystallized un-drawn PP fibers were acquired with high mechanical properties. with

Figure 32 shows fibrillated break-amorphous orientation and high crystalline factors of 0.87 and 0.95 , respectively, which demonstrate after only 1.34 draw ratio an unusual structural development for the treated fibers. Increasing by $9^{\circ} \mathrm{C}$ in the second melting peak for the treated fibers was observed by the DSC scan, which indicate the high level of molecular order and stable phase of the thermodynamically. Also, fiber tenacity reached $12 \mathrm{~g} / \mathrm{d}$ after the hot drawing with drawing ratio of 1.49 , while the initial modulus was greater than 150 $\mathrm{g} / \mathrm{d}$ and the ultimate elongation at break was approximately $20 \%$.

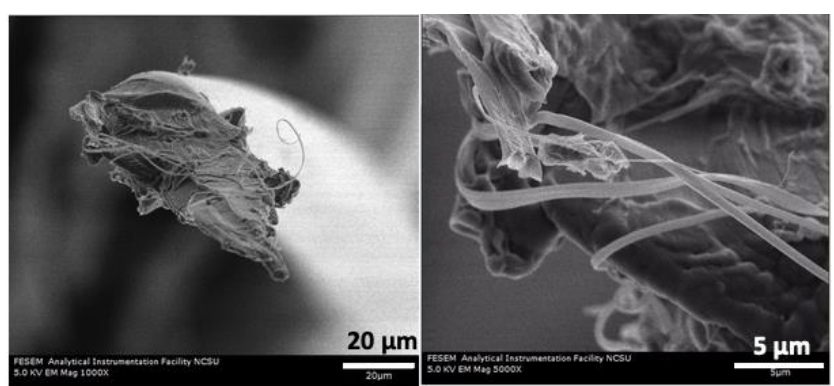

Figure 32. Cross Section of Drawn Treated PP Fiber by SEM (Reprinted with permission Copyright Springer Nature, 2013, Avci et al., 2013).

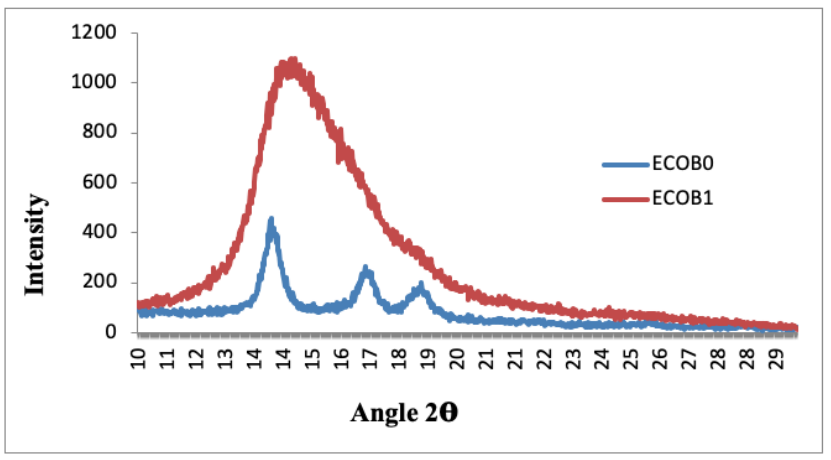

Figure 33. Equatorial XRD Profile of PP (ECOB1) AsSpun Fibers Spun with ECOB and (ECOB0) without ECOB (Avci et al., 2013). 
Eskişehir Osmangazi Üniversitesi Mühendislik ve Mimarlık Fakültesi Dergisi 27(2), 130 - 155, 2019

The other most common member of polyolefin family is polyethylene. In general, high performance of this fiber is produced by gel spinning method because this polymer is high viscous which limits the utilization of melt spinning production process. In addition to the high degree of entanglement of the molecular chains which decrease the drawing ratio. The detailed information and process conditions for the production of high-performance PE fibers are given in the next section of high-performance fiber production techniques.

\subsection{Inorganic Fibers}

Inorganic fibers might be described as fibers composed of inorganic and organometallic compounds over $99 \%$. They are not basically made up of polymer precursors, instead ceramic or metallic in nature. Due to that reason conventional textile fiber production systems are generally not suitable for inorganic fiber production. Comparatively complicated processes such as chemical vapor deposition, modified spinning techniques, and high temperature treatments would be utilized. Due to its fragile nature, inorganic fibers are commonly used in composite materials as reinforcement either in staple or continuous forms. Glass and Carbon fibers are the most used inorganic fibers in composite applications. High thermal stability (over $1000{ }^{\circ} \mathrm{C}$ for $\mathrm{C}$ fibers) and corrosion resistance are among their other features superior to their organic counterparts. Four of the commercially available inorganic fibers carbon (CF), glass (GF), boron, and SiC fibers, their production methods and properties will be reviewed.

\subsubsection{Carbon Fiber}

Though being organic in nature, $\mathrm{CF}$ is classified as inorganic due to pure sp2 bonded carbon chemistry. The theoretical strength for the single graphite crystal is calculated to be $150 \mathrm{GPa}$. However practical solutions have not been yet reached to that value, though Hexcel recently announced tensile strength of $8 \mathrm{GPa}$ from the PAN precursors. Inevitable defects at various scales were reported. Those can be 1) Atomic scale vacancies, interstitials and impurities. 2) Unoriented sheets and noncrystalline regions 3) Size of the graphene sheets and 4) Microheterogeneities such as skin-core. CF also exhibit very high modulus (up to $1 \mathrm{TPa}$ ), low density (ranged between 1.75 and $2.15 \mathrm{~g} / \mathrm{cm}^{3}$ ) and superior electrical conductivity $\left(10^{6} \mathrm{~S} / \mathrm{m}\right)$. The very first CF was produced via carbonization of cellulose precursors to be served as lamp filaments. However, it was not until 1960s that their excellent mechanical properties were noticed by industry. Union Carbide issued several
Journal of Engineering and Architecture Faculty of Eskisehir Osmangazi University 27(2), 130-155, 2019

patents on the production of high-performance CFs from rayon precursors (Schalamon and Bacon, 1973; Watts, 1968; Cross, Ecker and Stein, 1964). In 1961 Shindo reported carbonization procedure for polyacylonitrile (PAN), which became dominant system in the market due to high C yield of PAN (around 50\%) [A. Shindo in Report of the Government Industrial Research Institute, Osaka, Japan, 1961.] Any polymer having a significant C content might be precursors for $\mathrm{C}$ fibers. Studies were reported on conversion of nonheterocyclic aromatic polymers such as polyacrylether, polyamides; heterocyclic high temperature resistance organic polymers such as polyimides, polybenzimidazole and linear thermoplastic polymers such as polyethylene, polypropylene, polyvinyl chloride. However, none of them have reached to the success of PAN and pitch due to low $\mathrm{C}$ yield, process economics or poor mechanical properties (Chand, 2000). Today $90 \%$ of CF production comes from PAN based precursors. Polymers for use in developing high-performance carbon fiber should possess high molecular weight $\left(\sim 10^{5}\right)$. in addition to optimum molecular weight distribution, and minimum molecular defects (Morris and Weisenberger, 2014). Even presence of initiator residues from polymerization of PAN is effective on resultant CF properties. Also, comonomer ratio should not exceed $5 \mathrm{~mol} \%$ since that deteriorates cyclization behavior (Frank, Hermanutz and Buchmeiser, 2012).

Stabilization is the most time-consuming procedure, where PAN is converted into $\mathrm{N}$-containing ladder-type polymer and becomes thermally stable against decomposition. $\mathrm{C}$ content reaches to $50-65 \%$ of the total mass, while density of the fiber increases \%15-20. Carbonization process is than conducted on stabilized polymer above $1200^{\circ} \mathrm{C}$ in inert atmosphere $\mathrm{N}$ or $\mathrm{Ar}$. Ar can be preferred for high carbonization temperatures $\left(2000{ }^{\circ} \mathrm{C}\right)$, due to reactivity of $\mathrm{C}$ towards $\mathrm{N}$ to form cyanogen. At higher temperatures turbostratic structure converts into graphitic, leading to higher modulus, at an expense of lower strength

Pitch as another commercialized precursor, can be produced from petroleum, coal or pyrolyzed polymers. Compared to PAN based CFs, pitch-based CFs exhibit larger modulus (up to $900 \mathrm{GPa}$ ), however their tensile strength is average (around $3 \mathrm{GPa}$ ). Pitch is melt spun at around $350{ }^{\circ} \mathrm{C}$, forming well-oriented polyaromatic molecules in microdomains. After proper stabilization, as spun fiber leaves the $\mathrm{H}$ residues. To reach such high modulus pitch is graphitized around $2000{ }^{\circ} \mathrm{C}$.

\subsubsection{Glass Fiber}

Glass fiber is one of the cheaper alternatives as a composite reinforcer. It was invented by Russell G. Slayter to be used as an insulation material, which is still 
Eskişehir Osmangazi Üniversitesi Mühendislik ve Mimarlık Fakültesi Dergisi 27(2), 130 - 155, 2019

widely used. Raw materials with required composition (silicates, boric acid, soda, clay, metal oxides etc.) are blended to form batch. Silica based melts is spun into filaments using Pt/Ro alloy bushings having orifices ranging from 0.76 to $2.03 \mathrm{~mm}$. Then it is attenuated at speeds up to $60 \mathrm{~m} / \mathrm{sec}$, where it cools rapidly to prevent crystallization. Manufacture method vary according to end-use though forcing the melt through thermally stable bushings is the most common. It might be drawn via pneumatic-centrifugal (Chen, Cheng, Chen, Zhang, Yang and Wang, 2013) forces (also called cascade spinning) which is utilized for insulation and filtration purposes. Film formers, binders, lubricants, coupling agents, antistatic agents might be coated over to glass surface to enhance integrity, to protect fiber or to
Journal of Engineering and Architecture Faculty of Eskisehir Osmangazi University 27(2), 130-155, 2019

further improve properties ("High Strength Glass Fibers", 2019).

To reduce the spinning temperature and improve drawability various chemicals might be added, which might be removed later (Asobe, 1997). Glass fibers at higher purity might also be produced from sol-gel based precursors (Sakka and Kamiya, 1982; Kim, Kim and Knowles, 2006). E-glass which contains less than $1 \%$ wt. alumino-borosilicate is the most common glass fiber, besides there are grades which are stronger (R- and SGlass) or durable in acidic conditions (ECR-glass). Sglass composites even find applications in aircraft composites. Chemical compositions are prominent features of the commonly used GFs are given in Table 9.

Table 9.

Chemical Composition and Properties of Commonly Used Glass Fibers ("High Strength Glass Fiber ", 2019)

\begin{tabular}{|c|c|c|c|c|c|c|c|c|}
\hline & \multicolumn{5}{|c|}{ Chemical composition (\%) } & \multirow{2}{*}{$\begin{array}{c}\text { Tensile } \\
\text { Strength } \\
\text { (GPa) }\end{array}$} & \multirow{2}{*}{$\begin{array}{l}\text { Modulus } \\
\text { (GPa) }\end{array}$} & \multirow[t]{2}{*}{ Prominent feature } \\
\hline & $\mathrm{SiO}_{2}$ & $\mathbf{A l}_{2} \mathbf{O}_{3}$ & $\mathrm{~B}_{2} \mathrm{O}_{3}$ & $\mathrm{CaO}$ & Mg0 & & & \\
\hline C Glass & 65 & 4 & 6 & 14 & 3 & 3.3 & 68.9 & $\begin{array}{l}\text { Stable against corrosive } \\
\text { acidic environment }\end{array}$ \\
\hline D Glass & 74 & 0.3 & 22 & 0.5 & - & 2.4 & 51.7 & $\begin{array}{l}\text { A low dielectric constant } \\
\text { for electrical purposes }\end{array}$ \\
\hline E Glass w/B & $52-56$ & $12-16$ & $5-10$ & $16-25$ & $0-5$ & 3.4 & 72.3 & High strength and \\
\hline E Glass w/o B & 59 & $12-13$ & - & $22-23$ & 3 & & & electrical resistivity \\
\hline \multirow[t]{2}{*}{ ECR Glass } & $54-62$ & $9-15$ & - & $17-25$ & $0-5$ & 3.4 & 80.3 & $\begin{array}{l}\text { Electrical resistivity, and } \\
\text { acid }\end{array}$ \\
\hline & & & & & & & & corrosion resistance \\
\hline \multirow[t]{2}{*}{ R Glass } & $60-65$ & $17-24$ & - & $5-11$ & $6-12$ & 4.1 & 85.5 & Strength and acid \\
\hline & & & & & & & & corrosion resistance \\
\hline \multirow[t]{2}{*}{ S2 Glass } & $64-66$ & $24-26$ & - & - & $8-12$ & 4.9 & 86.9 & High strength, \\
\hline & & & & & & & & modulus \\
\hline
\end{tabular}

Organic fibers are composed of oriented chains, forming semicrystalline morphology. In contrary glass fibers are amorphous despite having linear silica chains. An early study by Anderegg (1939) reported that the tensile strength of glass fiber showed increase from 0.7 to 6 $\mathrm{GPa}$, when fiber diameter was reduced to $2.5 \mu \mathrm{m}$ from $19 \mu \mathrm{m}$. However later Otto (1955) showed that it was about the fiber formation procedure rather than the diameter that causes the excessive increase in mechanical properties. No significant effect of diameter was observed after producing the fibers at identical conditions. Cooling rate (Yue, Von der Ohe and Jensen, 2004), melting history and mechanical stretching (Brow, Lower, Kurkjian and Li, 2009) are dominating the process parameters on the morphological and reported mechanical properties mechanical properties of glass fibers; which is universal for all performance fibers.

Glass fiber is the most produced inorganic fiber having wide applications due to its low cost, but there are still concerns about its carcinogenic effects ("Fiber glass" 2019). It was stated to be even more carcinogenic than 
Eskişehir Osmangazi Üniversitesi Mühendislik ve Mimarlık Fakültesi Dergisi 27(2), 130 - 155, 2019

asbestos (Infante, Schuman, Dement and Huff, 1994). Up to now glass fiber-based insulation products were installed in millions of houses over the world. However high-performance GFs are used in composites, where the fiber is completely embedded into polymer matrix. The effect will be minimal compared to other applications.

\subsubsection{Boron Fiber}

Boron fibers or commonly known boron filaments, which were first reported for structural application in 1960 , is one of the high strengths and high modulus inorganic materials (Gaule, Breslin, Pastore and Shuttleworth, 1960). It is amorphous elemental boron in which the halide-process boron filaments can be synthesized by chemical reduction of boron halides such as trichloride $\left(\mathrm{BCI}_{3}\right)$ or boron tribromide $\left(\mathrm{BBr}_{3}\right)$ at the surface of a substrate wire like tungsten by hydrogen reduction method in the form of borided tungsten core with amorphous boron. It shows a relatively large diameters of 102-micron and 142-micron ("Boron Fiber", 2014). It was especially developed to explore new materials for aerospace applications which then utilized as component of different composite materials due to its unique combination of high strength, high modulus and low density (Burningham and Rumpel, 1967).

Boron filaments are also manufactured using laser assisted chemical vapor deposition (CVD) technique is therefore costlier than graphite. Complex threedimensional helical structures for example amorphous boron fibers and crystalline boron springs can be obtained by the precisely controlling via laser beam and a micropositioning system with the smallest structures is about $1 \mu \mathrm{m}$. In this case, the amorphous boron filaments demonstrated improved mechanical properties with the values of modulus of elasticity (MOE) $450 \mathrm{GPa}$, fracture strain of $3.7 \%$ and fracture stress of $17 \mathrm{GPa}$ even if the crystalline boron springs showed moderate mechanical properties (Johansson, Schweitz, Westberg and Boman,, 1992).

In addition to a wide range of aerospace applications, different specialized applications for boron can be found such as sporting goods applications as a golf club shaft, reinforcement for ceramics, and so on.

\section{Production Techniques of High-Performance Fibers}

\subsection{Dry-Wet Jet Spinning}

Rigid rod polymer like PBO, M5 and Kevlar are decomposed at high temperature without melting. So, melt-spinning technique cannot be used for these fibers.
Journal of Engineering and Architecture Faculty of Eskisehir Osmangazi University 27(2), 130-155, 2019

These fibers can be spun via dry-wet jet spinning technique. In this technique, spinning solution is extruded via spinnerets and elongational strain was applied through a tiny air gap, as shown in Figure 34.

The-spinneret holes have an important role. Under shear strength, the crystal domains turn to be orientated and elongated in the deformation direction. When the polymer solution reaches the tiny air gap, the stretching occurred. It is affected by the draw ratio, which is the ratio of the fiber velocity as it moves out of the coagulation bath to the polymer velocity as it moves out of the spinning (Hearle, 2001).

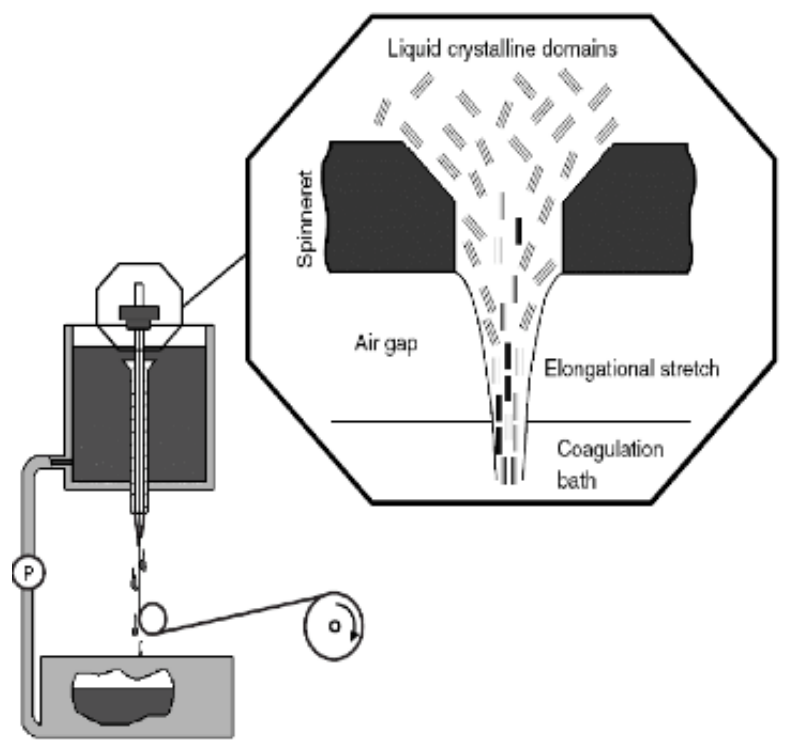

Figure 34. Schematic diagram of liquid crystal solution extruded in dry-jet wet spinning process in The Dry-Jet Wet-Spinning Process (Hearle, 2001).

\subsection{Gel Spinning}

The creation of highly oriented polyolefin fibers with high mechanical properties can occurred in extended gel spinning process. In this method, ultra-high molecular weight polymers are used to manufacture fibers products. The main point of this technique is to reduce molecular entanglement in the gel and to obtain an efficient stretching of the polymer chains in the flow media.

Ultra-high molecular weight PE fiber (UHMWPE) is produced through the solution/gel spinning technology with an ultra-high draw ratio to get minimal intermolecular entanglements. UHMWPE is synthesized from ethylene with metallocene catalysis polymerization. This method has much more advantages than Ziegler-Natta technique because of getting much higher molecular weight. HMWPE fibers show High mechanical and physical properties, for 
Eskişehir Osmangazi Üniversitesi Mühendislik ve Mimarlık Fakültesi Dergisi 27(2), 130 - 155, 2019

example, high modulus, high strength, low specific weight, high cut and abrasion resistance, high impact resistance, and high chemical resistance. (Xu and Farris, 2007). Dyneema and Spectra are two popular brand names for the same-based polymer which are very strong fibers. These fibers are produced using gelspinning method via a spinneret to acquire high oriented of UHMWPE. Table 10 demonstrates physical properties of Dyneema SK60, SK65, SK75, SK76 (Afshari et al., 2008).

Table 10

Different Types of Dyneema Mechanical Properties (Afshari et al., 2008).

\begin{tabular}{lcccc}
\hline & \multicolumn{4}{c}{ Physical Properties of Dyneema } \\
\cline { 2 - 5 } & SK 60 & SK 65 & SK 75 & SK 76 \\
\hline Density (g/cc) & 0.97 & 0.97 & 0.97 & 0.97 \\
Strength & 2.8 & 3.1 & 3.5 & 3.7 \\
$\quad$ Tenacity (N/tex) & 32 & 35 & 40 & 42 \\
Tenacity (g/den) & 2.7 & 3.0 & 3.4 & 3.6 \\
Tensile strength (GPa) & 91 & 97 & 110 & 120 \\
Modulus & 1025 & 1100 & 1250 & 1350 \\
$\quad$ Specific modulus (N/tex) & 99 & 95 & 107 & 116 \\
Specific modulus (g/den) & 3.5 & 3.6 & 3.8 & 3.8 \\
$\quad$ Modulus (GPa) & & & & \\
Elongation (\%) & &
\end{tabular}

Smith and Lemstra (1979) revealed in one of the first publications on gel spinning method. They used high molecular weight polyethylene $\left(\bar{M}_{w}=1.5 \times 10^{6}\right)$ with decalin solvent. Dilute and concentrated solutions were used to spin polyethylene monofilaments. $2 \mathrm{wt} \%$ polyethylenes in decalin at $150{ }^{\circ} \mathrm{C}$ was prepared for the dilute solution method. Then, the high viscosity polymer was pumped at $130{ }^{\circ} \mathrm{C}$ through capillaries, and these liquid filaments were quenched in cold water which had almost all the decalin. Finally, these as-spun gel fibers were drawn at different drawing ratios in hot air oven at $120^{\circ} \mathrm{C}$ under strain rate of $1 \mathrm{~s}^{-1}$. Figure 35 shows stressstrain curve of spun-drawn PE monofilaments solution. As seen, the drawing process has increased the produced fibers mechanical properties with $90 \mathrm{GPa}$ for modulus, 3.0 $\mathrm{GPa}$ for strength were reported as the highest values after $32 \mathrm{x}$ draw ratios. They also demonstrated that decalin had a slight plasticizing effect to increase the attained draw ratio after removing the solvent in the drawing stage. However, they observed similar mechanical properties at the same draw ratio with and without solvent.
Journal of Engineering and Architecture Faculty of Eskisehir Osmangazi University 27(2), 130-155, 2019

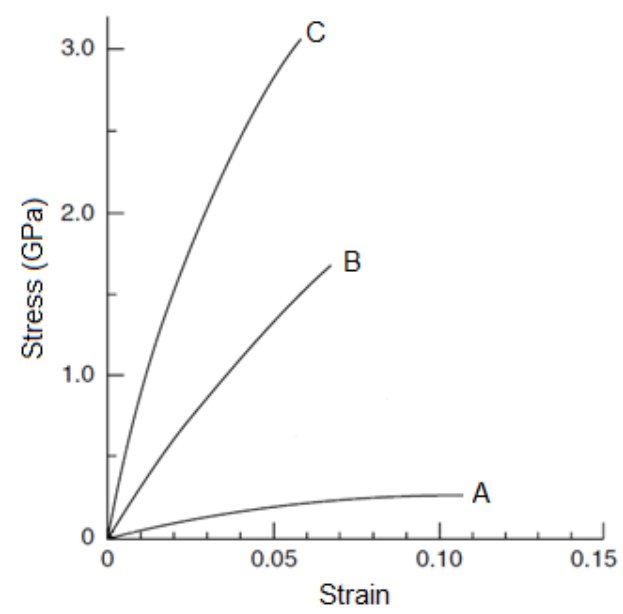

Figure 35. Stress-Strain Curves for Gel Spun-Drawn Polyethylene Fibers. Draw Ratios: (A):3, (B): 15, (C): 32 (Smith and Lemstra,1979).

For concentrated solution, 10-50 wt. \% of solvent, the fibers did not show the same drawability compared with the fibers spun from dilute solutions. The maximum draw ratio of $5 \mathrm{x}$ was observed at the draw temperature of $120^{\circ} \mathrm{C}$. This interesting phenomenon was explained as primarily due to occurred homogeneous and continuous structure of HMWPE in the dilute solution. Furthermore, a substantially smaller number of entanglements were formed when compared with the concentrated solution. This non-uniform structure with a very large number of entanglements for concentrated solution caused to increase numerous defects which led to fracture upon drawing.

Isotactic polypropylene ( $i$-PP) is another common polymer for producing high-performance fibers. It also has significantly higher melting temperature than polyethylene. Researchers have attempted to produce fibers of UHMW $i$-PP using the gel spinning technique. A high-molecular weight polypropylene has been used (Cebe and Grubb, 1985) to investigate gel-films formation by using $1 \%$ polymer. The hot solutions of $i$ $\mathrm{PP}$ were quenched in decalin to $-25^{\circ} \mathrm{C}$, and then left for a few hours. Ultra-drawn dried PP-gels with a draw ratio of $57 x$ had a very close value for the theoretical modulus and strength of polypropylene. In addition, Kavesh and Prevorsek, (1983) disclosed in a US Patent production HPPE and PP fibers. The most preferable molecular weight average of polypropylene used was around $2,000,000$ (11 IV), IV represents the intrinsic viscosity of the used polymer that was determined by decalin at 135 ${ }^{\circ} \mathrm{C}$. A solution of ultrahigh molecular weight of polypropylene was obtained using a relatively nonvolatile solvent. Then, this solution was extruded through an aperture to produce an indefinite length of first gel after exposed to cooling process. The second step provided to form a second gel by the extraction of 
Eskişehir Osmangazi Üniversitesi Mühendislik ve Mimarlık Fakültesi Dergisi 27(2), 130 - 155, 2019

first gel into a volatile solvent and a low-porosity xerogel was manufactured after drying process of the second gel. Finally, these first, second and/or a combination of gels was drawn to acquire high modulus and high tenacity polypropylene fibers. The drawing process could be applied after the first and second gel formation by a single stage or more than two stages. In general, they applied two or more than two drawing stages and the last stage occurred under temperature between $135-150^{\circ} \mathrm{C}$. A unique type of polypropylene fibers with the tenacity value of at least $8 \mathrm{~g} / \mathrm{d}$ and a at least tensile modulus of $160 \mathrm{~g} / \mathrm{d}$ were observed. These PP fibers also demonstrated an elongation at break less than approximately $20 \%$ and the main melting temperature of $160{ }^{\circ} \mathrm{C}$ with porosity less about $10 \%$.

In addition, Chawla (2005) has determined the difference between polyethylene, UHMWPE, and polypropylene fibers for the tenacity and modulus performances. In general, polypropylene does not show a very high modulus and crystallinity as polyethylene fibers that generally could have high modulus and crystallinity. This is because the side groups for polypropylene vs. highly linear polyethylene molecular chains. These bulky side groups prevent to manufacture an orderly arrangement of molecular chains and high degree of crystallinity (Chawla, 2005).

\subsection{A Recent Development of High-Performance Fibers from Linear Polymers: Liquid Isothermal Bath}

A highly oriented, crystalline and modulus thermoplastic fiber with high tenacity could be produced by the liquid isothermal bath (LIB) process. Dr. Cuculo et al. (1993) developed a new method which related to a melt-spinning process to produce highly oriented and highly crystalline fiber with low shrinkage and high tenacity. A melt-spun fiber pass into a liquid bath was at least about $30^{\circ} \mathrm{C}$ above the glass transition temperature. After withdrawing the fibers, they were wound up at speed between $2500-7000 \mathrm{~m} / \mathrm{min}$. It was then modified, which is safer, need less capital equipment and energy, and the one of the most important features is the industrially applicable method that is called a novel horizontal liquid isothermal bath (hIB) (Figure 36).

In a traditional melt spinning and drawn processes; the molten polymers are forced via spinning pumps through spinnerets to form filaments and then the molten filaments are cooled to achieve solidified filaments, which have low crystallinity, orientation and inferior mechanical properties. They are stretched or drawn in one or more steps to obtain fiber with high oriented polymer chain along fiber axis but during this process low dimensional stability also can be occurred. For the
Journal of Engineering and Architecture Faculty of Eskisehir Osmangazi University 27(2), 130-155, 2019

melt spinning that was modified by liquid isothermal bath, the superior mechanical properties, excellent dimensional stability and controlled threadline dynamics can be manufactured with drawing (max DR of 1.5) and annealing processes.

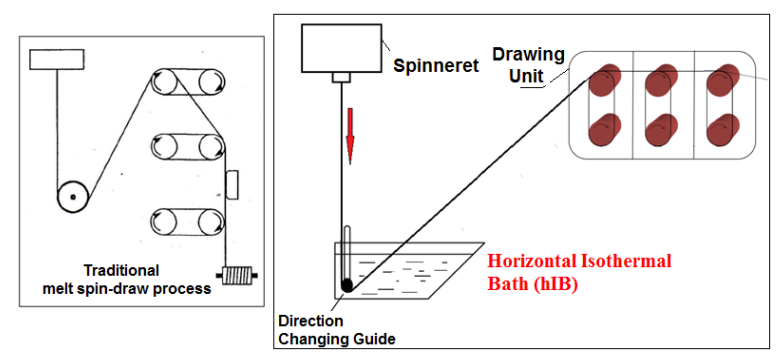

Figure 36. Schematic Comparison of Traditional SpinDraw and Hib Processes.

It has been found that there is a dramatic increase in the tenacity of the hIB-spun PET $(0.97 \mathrm{dL} / \mathrm{g})$ filaments, at a very low draw ratio, $1.28 \mathrm{DR}$, with the hot-drawn process. The fiber tenacity of $11.39 \mathrm{~g} / \mathrm{d}$ was observed and the fiber modulus reached $134.9 \mathrm{~g} / \mathrm{d}$ with take up speed of $3000 \mathrm{~m} / \mathrm{min}$ at 7.78 for the fiber denier. The similar trend is also recorded for Poly(ethylene naphthalate) (PEN) fibers (Cuculo et al., 1998) by developing a unique precursor morphology. The polymer molecules interact with hIB get a more chance to thoroughly extend, order and orient during the mobile molten state. As a result, a very high degree of oriented crystalline synthetic filament with higher mechanical properties can be produced after very low draw ratios.

In addition to polyester fibers, high-performance as spun and drawn PP and nylon filaments (Avci et al., 2015) are produced by hIB method. After the optimum process conditions were achieved in which for tenacity more than $7.5 \mathrm{~g} / \mathrm{d}$ and for modulus more than $75.5 \mathrm{~g} / \mathrm{d}$ for undrawn and after drawing of only 1.49x DR with $120{ }^{\circ} \mathrm{C}$ drawing temperature about 197 and $12.21 \mathrm{~g} / \mathrm{d}$ for the modulus and tenacity, respectively. The elongation at break of the resulted fibers demonstrated $16 \%$ for about 7 denier PP filament although a very low molecular weight of the polymer with melt flow rate of $36 \mathrm{~g} / 10$ min was used. PP theoretical modulus is 35-42 $\mathrm{GPa}, 275-330 \mathrm{~g} / \mathrm{d}$, when measured using X-ray techniques with the theoretical strength of $3.9 \mathrm{GPa}$ and 30g/d (Mukhopadhyay et al., 2004). In this case especially, the modulus value reaches the theoretical value by using this new novel technique. After drawing process of $1.49 \mathrm{x}$ DR, thermal properties (Figure 37), degree of crystallinity (66.6\%), crystalline and amorphous orientation factors $\left(f_{c}\right.$ and $f_{a}$ with the value of 0.95 and 0.94 , respectively), and the formation of 
Eskişehir Osmangazi Üniversitesi Mühendislik ve Mimarlık Fakültesi Dergisi 27(2), 130 - 155, 2019

fibrillar structures were obtained. These improved parameters and features even for undrawn treated fibers are clear evidences for developing a unique structure neither utilizing conventional drawing equipment nor using toxic solvents with generating a lot of undesired by-products.

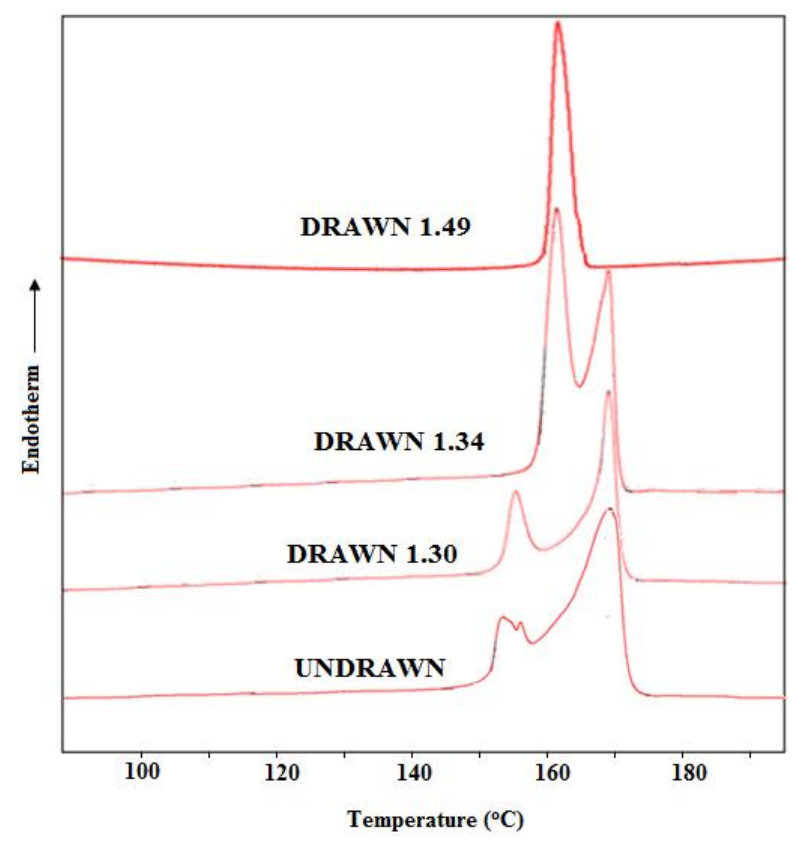

Figure 37. DSC Curves of Low MW PP Fibers Spun With hIB at Various Draw Ratios at The Drawing Temperature of $120^{\circ} \mathrm{C}$ (Avci et al., 2015).

\subsection{Recent Developments in Carbon Fiber Production}

1 wt.\% C nanotubes incorporation into PAN precursor increased tensile strength of resultant $\mathrm{C}$ fibers up to 4 $\mathrm{GPa}$ in batch processing system. Since the nanotubes were added into dope, homogenous, well oriented distribution was observed after the two-step drawing (Liu, Chae and Kumar 2011). Besides addition of CNTs was found to be enhancing chain orientation of PAN, and reducing cross-linking reaction activation energy (Liu, Chae and Kumar, 2011) Kumar et al observed 25\% increase in compressive strength and 50\% in torsional modulus upon implantation of B into $\mathrm{C}$ fibers (Kumar, Anderson and Crasto, 1993).

Apart from that several studies were concentrated on surface treatment of as prepared C fibers. Wet chemical (Severini, Formaro, Pegoraro and Posca, 2002), electrochemical (Yue, Jiang, Wang, Gardner and Pittman, 1999), irradiation by plasma (Wen, Yang, Ou, Wu, Chou, Luo and Chang, 2006), ion treatment (Ivanov, Gavrilov, Belyh, Ligacheva, Galijeva, Ligachev and Sohoreva, 2007) or grafting ( $\mathrm{Xu}, \mathrm{Wu}, \mathrm{Sun}, \mathrm{Jiao}, \mathrm{Li}, \mathrm{Chen}$ and $\mathrm{Lu}$,
Journal of Engineering and Architecture Faculty of Eskisehir Osmangazi University 27(2), 130-155, 2019

2008) are among them where rather than the bulk properties, the largest interfacial strength is intended in composite applications. Besides electrochemical properties of carbon nanofibres was found to be promising for Li ion battery parts (Kim, Yang, Kojima, Yoshida, Kim, Kim and Endo, 2006; Li, Lin, Xu, Yao, Zhang, Toprakci, Alcoutlabi and Zhang, 2012; Wang, Yu, Chen and Chen, 2008). One of the studies showed that even mechanical properties of carbon nanofibres might be as strong as their micro counterparts. Tensile strength of $3.5 \mathrm{GPa}$ and modulus of $172 \mathrm{GPa}$ have been reported after carbonization at temperatures up to $1700{ }^{\circ} \mathrm{C}$ (Arshad, Naraghi and Chasiotis, 2011).

Recently carbon fibers with different cross-sections were also produced by different groups. Two basic advantages were intended for such modification. Using hollow carbon fibers, it might be possible to reduce carbon fiber density in composites. To our knowledge strongest hollow carbon fibers (tensile strength and modulus of 2.6 and $230 \mathrm{GPa}$, respectively) were produced by carbonizing hollow PAN fibers spun from a C shaped spinnerette (Liu and Kumar, 2012). Another advantage might be increase in surface area, which will theoretically increase the total interface with resin. Naskar et al produced $C$ fibers of trilobal, amoeba like and flower contours from PE based precursors. However, their mechanical properties were significantly poor compared to regular CFs (tensile strength of 1.1 GPa and modulus of $103 \mathrm{GPa}$ ) (Hunt, Saito, Brown, Kumbhar and Naskaet, 2012) This might be due to nonhomogeneous distribution of Poisson contraction through noncircular geometry. Surface of PE derived C was mainly composed of graphitic structure; whereas porous disordered near the core, which resulted with 330-fold higher BET surface area. Most probably surface layer, which is subjected to high shear forces, exhibited ordered structure. Recyclable carbon fiber composite, polyvinyl alcohol (PVA) grafted to single-walled carbon nanotubes (SWCNTs) to improve mechanical properties are some other recent promising strategies (Wang, Ma, Li, Xu, Wang, Yuan, Zhou, You and Zhu, 2019; Lee, Clancy, Fernández-Toribio, Anthony, White, Solano, Leese, Vilatela and Shaffer, 2019).

Unfortunately, most of the studies in the academic literature were performed in batch processes, which might be misleading for the conclusion. Applied tension should be maximized (till just before breaking the fiber) through the stabilization and the carbonization stages. Hence one of the requirements of performance fiber production is high orientation which is indispensably ignored during batch processes (Liu et al., 2011). 
Eskişehir Osmangazi Üniversitesi Mühendislik ve Mimarlık Fakültesi Dergisi 27(2), 130 - 155, 2019

\section{Future Directions and Concluding Remarks}

High modulus and high tenacity fibers offer an interesting arena to fiber manufacturers and scientists to create high performance products with high strength and greater stability. There are so many different types of methods available to produce high modulus and high strength fibers as already been explained in the previous chapters.

With recent development and advances in high performance fibers with widely ranging properties is becoming a more realistic goal to withstand harsh operating environments for a variety of applications such as aerospace, aircraft, airline, medical, automotive, energy, transportation and etc. It could be summarized that high-strength PE, carbon fiber and aramid fiber are the most widely applied in high-strength applications, even if carbon fibers in industrial fields shows the most rapid demand growth in recent years, and in many other technical structural parts such as aerospace and aviation, automobile, sports goods, and etc. in the near future. In the case for high performance PE fiber which has established itself in technical applications because of their very high resistance to chemicals and anticorrosion properties in addition to remarkable mechanical properties, being widely used in specialized applications such as safety protection, sports goods, and so on.

Therefore, they are classified as the different optimized categories. Although Figure 38 compares some different high performance-fibers for their specific modulus versus specific strength, it is hard to draw a conclusion about future directions directly because of widely ranging properties in addition to performance. For example, PAN-based fibers most probably will be used and dominate applications where strength is critical, on the other hand pitch-based fibers will be utilized where heat transfer or stiffness is crucial parameter. Therefore, it is important to choose a high-performance fiber that can maintain its properties to meet the needs of specific applications.
Journal of Engineering and Architecture Faculty of Eskisehir Osmangazi University 27(2), 130-155, 2019

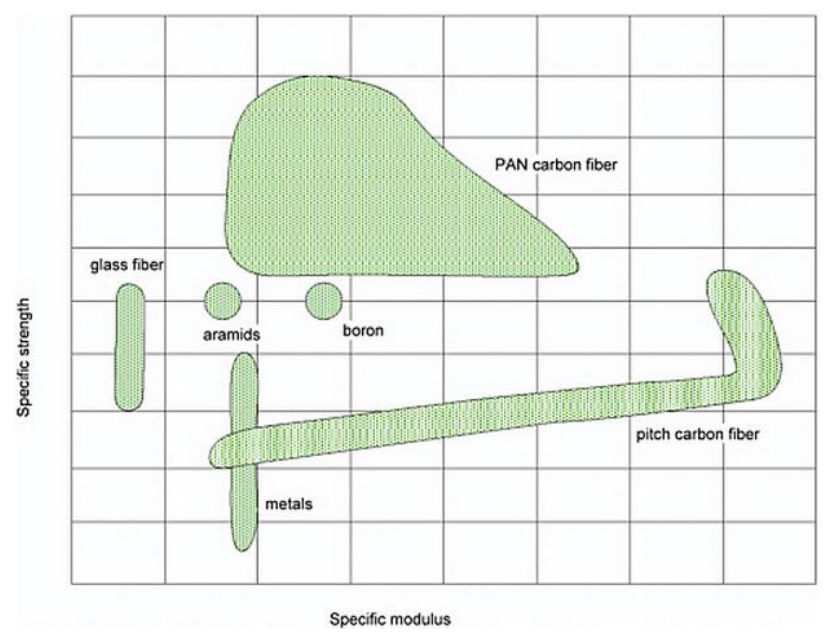

Figure 38. Comparison of Some Different High Performance-Fibers in The Terms of Specific Modulus Versus Specific Strength ("High-Performance Structural Fibers for Advanced Polymer Matrix Composites", 2019).

Future advances in high performance fibers, as well as in related fields, will require thoughtful integration on conservation of resources and raw materials. In addition, energy use, ecological and economic benefits especially for light-weight structures, priceperformance ratios are some important factors lives up to its true applications potential (Bernhard Jahn, 2014). It lends credence to the statement that in the near future even now the ecological impact of the product is becoming more important than the economic aspects, which will be one of the important the decisive factor that people use for selecting a product for their need.

\section{Acknowledgment}

The authors gratefully acknowledge funding by Scientific and Technological Research Council of Turkey (TUBITAK) with the project number of 117Z673. The authors also thank Dr. Hamed Ghorbanpoor for his great help.

\section{Conflict of Interest}

No conflict of interest was declared by the authors.

\section{References}

Afshari, M., Sikkema, D.J., Lee, K., Bogle, M., (2008). High performance fibers based on rigid and flexible polymers. Polymer Reviews, 48(2), 230-274. doi: https://doi.org/10.1080/15583720802020129 
Eskişehir Osmangazi Üniversitesi Mühendislik ve Mimarlık Fakültesi Dergisi 27(2), 130 - 155, 2019

Anderegg, F., (1939). Strength of Glass Fires. Industrial \& Engineering Chemistry, 31(3), 290-298.

Arshad, S.N., Naraghi, M., Chasiotis, I., (2011). Strong carbon nanofibers from electrospun polyacrylonitrile. Carbon 49(5), 1710-1719. doi: https://doi.org/10.1016/j.carbon.2010.12.056

Asobe, M., (1997). Nonlinear optical properties of chalcogenide glass fibers and their application to alloptical switching. Optical Fiber Technology, 3(2), 142-148. https://doi.org/10.1006/ofte.1997.0214

Avci, H., Kotek, R., Toliver, B., (2015). Controlling of threadline dynamics via a novel method to develop ultra-high performance polypropylene filaments. Polymer Engineering \& Science, 55(2), 327-339. doi: https://doi.org/10.1002/pen.23908

Avci, H., Kotek, R., Yoon, H., (2013). Developing an unusual formation of a precursor for crystallization of high performance PET fibers using a low molecular weight polymer. In Abstracts of Papers of The American Chemical Society.

Avci, H., Kotek, R., Yoon, J., (2013). Developing an ecologically friendly isothermal bath to obtain a new class high-tenacity and high-modulus polypropylene fibers. Journal of materials science 48 (22), 77917804. doi: $10.1007 / \mathrm{s} 10853-013-7427-1$

Avci, H., Güzel, F.D., Erol, S. and Akpek, A., (2018). Recent advances in organ-on-a-chip technologies and future challenges: a review. Turkish Journal of Chemistry, 42(3), 587-610. doi: 10.3906/kim-1611-35

Bernhard Jahn, E.W., (2014). Composites Market Report (2019). Web access server address: http://www.carbon-composites.eu/sites/carboncomposites.eu/files/anhaenge/13/09/17/ccev-avkmarktbericht 2013-final-englisch-bj.pdf.

Boron Fiber 2014. (2019). Web access server address: http://www.specmaterials.com/boronfiber.htm.

Bourbigot, S., Flambard, X., Duquesne, S., (2001). Thermal degradation of poly (pphenylenebenzobisoxazole) and poly (pphenylenediamine terephthalamide) fibres. Polymer international, 50,(1) 157-164. doi: https://doi.org/10.1002/10970126(200101)50:1<157::AID-PI617>3.0.CO;2-D

Brow, R.K., Lower, N.P., Kurkjian, C.R., Li, H., (2009). The effects of melt history on the failure characteristics of pristine glass fibres. Physics and Chemistry of Glasses, Society of Glass Technology

Burningham, N., Rumpel, W., (1967). Properties of boron fibers and composites. Polymer Engineering \&
Journal of Engineering and Architecture Faculty of Eskisehir Osmangazi University 27(2), 130-155, 2019

Science, $\quad 7(2), \quad$ 124-127. doi: https://doi.org/10.1002/pen.760070211

Calisir, M.D., Erol, M., Kilic, A. and Avci, H., (2016). Photophysical properties of phosphorescent elastomeric composite nanofibers. Dyes and Pigments, 125, 95-99. doi: https://doi.org/10.1016/j.dyepig.2015.09.036

Cansfield, D., Capaccio, G., Ward, I., (1976). The preparation of ultra-high modulus polypropylene films and fibres. Polymer Engineering \& Science, 16 (11), 721-724. doi: https://doi.org/10.1002/pen.760161102

Cebe, P., Grubb, D., (1985). Gel-drawn fibres of poly (vinyl alcohol). Journal of Materials Science, 20(12), 4465-4478.

Chae, H.G., Kumar, S., (2006). Rigid-rod polymeric fibers. Journal of Applied Polymer Science, 100(1), 791-802. doi: https://doi.org/10.1002/app.22680

Chand, S., (2000). Review carbon fibers for composites. Journal of Materials Science, 35(6), 1303-1313. doi: https://doi.org/10.1023/A:1004780301489

Chawla, K.K., (2005). Fibrous Materials. . Cambridge University Press.

Chen, Z., Cheng, X.Y., Chen, Z.F., Zhang, J., Yang, Y., Wang, J., (2013). Ultrafine glass fibers produced by centrifugal-spinneret-blow process. In Advanced Materials Research, 628, 27-32. doi: https://doi.org/10.4028/www.scientific.net/AMR.6 $\underline{28.27}$

Coates, P., Ward, I., (1979). Drawing of polymers through a conical die. Polymer, 20(12), 1553-1560. doi: https://doi.org/10.1016/0032$\underline{3861(79) 90024-7}$

Cross, C.B., Ecker, D.R., Stein, O.L., (1964). Artificial graphite process, Google Patents.

Cuculo, J.A., Tucker, P.A., Chen, G.-Y., Lundberg, F., (1993). Melt spinning of ultra-oriented crystalline filaments. Google Patents.

Cuculo, J.A., Tucker, P.A., Lundberg, F., Chen, J.-Y., Wu, G., Chen, G.-Y., (1998). Ultra-oriented crystalline filaments and method of making same. Google Patents.

Cunniff, P.M., Auerbach, M.A., Vetter, E., Sikkema, D.J., (2002). High performance "M5" fiber for ballistics/structural composites. 23. Army Science Conference, 1-8.

Dyneema. (2019). Web access server address: http://www.dyneema.com/emea/.

De Candia, F., Romano, G., Baranov, A., Prut, E., (1992). Dynamic-mechanical behavior of highly drawn 
Eskişehir Osmangazi Üniversitesi Mühendislik ve Mimarlık Fakültesi Dergisi 27(2), 130 - 155, 2019

isotactic polypropylene. Journal of applied polymer science, 46(10), 1799-1806. doi: https://doi.org/10.1002/app.1992.070461011

Fiber glass: a carcinogen that's everywhere. (2019). Web access server address: http://www.ejnet.org/rachel/rehw444.htm.

Fette, R.B., Sovinski, M.F., (2004). Vectran fiber time dependant behavior and additional static loading properties. National Aeronautics And Space Administration Greenbelt Md Goddard Space Flight Center.

Frank, E., Hermanutz, F., Buchmeiser, M.R., (2012). Carbon fibers: precursors, manufacturing, and properties. Macromolecular materials and engineering, 297(6), 493-501. doi: https://doi.org/10.1002/mame.201100406

Gaule, G., Breslin, J., Pastore, J., Shuttleworth, R., (1960). Optical and Electrical Properties of Boron and Potential Application, ft in JA Kohn, NF Nye, and GK Gaule (eds.): Boron-Synthesis, Structure, and Properties, Plenum Press, New York.

Grujicic, M., Bell, W., Arakere, G., He, T., Xie, X., Cheeseman, B., (2010). Development of a meso-scale material model for ballistic fabric and its use in flexible-armor protection systems. Journal of materials engineering and performance, 19(1), 22-39. doi: https://doi.org/10.1007/s11665-009-9419-5

Gupta, A., (2005). Improving UV resistance of high strength fibers. Web access server address: http://www.lib.ncsu.edu/resolver/1840.16/1092

Hearle, J.W., (2001). High-performance fibres. Elsevier.

High-Performance Structural Fibers for Advanced Polymer Matrix Composites. (2019). Web access server address: http://www.nap.edu/catalog.php?record id=11268

High Strength Glass Fibers. (2019). Web access server address: http://www.agy.com/wpcontent/uploads/2014/03/High Strength Glass Fib ers-Technical.pdf.

Holmes, G.A., Rice, K., Snyder, C.R., (2006). Ballistic fibers: a review of the thermal, ultraviolet and hydrolytic stability of the benzoxazole ring structure. Journal of Materials Science, 41(13), 4105-4116. doi: https://doi.org/10.1007/s10853-005-5597-1

Honeywell Advanced Fibers and Composites. (2019). Web access server address: http://www.honeywelladvancedfibersand composites.com/.

Hunt, M.A., Saito, T., Brown, R.H., Kumbhar, A.S., Naskar, A.K., (2012). Patterned functional carbon fibers from polyethylene. Advanced Materials, 24(18), 2386-
Journal of Engineering and Architecture Faculty of Eskisehir Osmangazi University 27(2), 130-155, 2019

2389. doi: https://doi.org/10.1002/adma.201104551

Infante, P.F., Schuman, L.D., Dement, J., Huff, J., (1994). Fibrous glass and cancer. American Journal of Industrial Medicine, 26(4), 559-584. doi: https://doi.org/10.1002/ajim.4700260413

Ivanov, M., Gavrilov, N., Belyh, T., Ligacheva, E., Galijeva, L., Ligachev, A., Sohoreva, V., (2007). Irradiation effects in carbon fibers after $\mathrm{N}+$-ion irradiation. Surface and Coatings Technology, 201(19-20), 83268328.

doi:

https://doi.org/10.1016/j.surfcoat.2006.12.034

Johansson, S., Schweitz, J.Å., Westberg, H., Boman, M., (1992). Microfabrication of three-dimensional boron structures by laser chemical processing. Journal of Applied Physics, 72(12), 5956-5963. doi: https://doi.org/10.1063/1.351904

Kavesh, S., Prevorsek, D.C., (1983). High tenacity, high modulus polyethylene and polypropylene fibers and intermediates therefore. Google Patents.

Kerr, M., Chawla, N., Chawla, K., (2005). The cyclic fatigue of high-performance fibers. JOM, 57(2), 6771. doi: https://doi.org/10.1007/s11837-005-0219$\underline{6}$

Kim, C., Yang, K.S., Kojima, M., Yoshida, K., Kim, Y.J., Kim, Y.A., Endo, M., (2006). Fabrication of electrospinning-derived carbon nanofiber webs for the anode material of lithium-ion secondary batteries. Advanced Functional Materials, 16(18), 2393-2397.

doi: https://doi.org/10.1002/adfm.200500911

Kim, H.W., Kim, H.E., Knowles, J.C., (2006). Production and potential of bioactive glass nanofibers as a nextgeneration biomaterial. Advanced Functional Materials, 16(12), 1529-1535. doi: https://doi.org/10.1002/adfm.200500750

Kotek, R., (2008). Recent advances in polymer fibers. Polymer Reviews, 48(2), 221-229. doi: https:// https://doi.org/10.1080/15583720802020038

Kumar, S., Anderson, D., Crasto, A., (1993). Carbon fibre compressive strength and its dependence on structure and morphology. Journal of Materials Science, 28(2), 423-439. doi: https://doi.org/10.1007/BF00357820

Kunugi, T., Ito, T., Hashimoto, M., Ooishi, M., (1983). Preparation of high-modulus and high-strength isotactic polypropylene fiber by zone-annealing method. Journal of Applied Polymer Science, 28(1), 179-189. https://doi.org/10.1002/app.1983.070280115 
Eskişehir Osmangazi Üniversitesi Mühendislik ve Mimarlık Fakültesi Dergisi 27(2), 130 - 155, 2019

Laughner, M., Harrison, I., (1988). Hot nip drawing: A rapid method of producing high modulus polypropylene films. Journal of applied polymer science, 36(4), 899-905. doi: https://doi.org/10.1002/app.1988.070360413

Lee, W. J., Clancy, A. J., Fernández-Toribio, J. C., Anthony, D. B., White, E. R., Solano, E., Leese, H. S., Vilatela, J. J., Shaffer, M. S., (2019). Interfacially-grafted single wall carbon nanotube/poly (vinyl alcohol) composite fibers. Carbon, 146, 162-171. doi: https://doi.org/10.1016/j.carbon.2019.01.075

Market Study: Polyethylene - HDPE (2nd ed.). (2019). Web access server address: http://www.ceresana.com/en/marketstudies/plastics/polyethylene-hdpe/.

Li, Y., Lin, Z., Xu, G., Yao, Y., Zhang, S., Toprakci, O., Alcoutlabi, M., Zhang, X., (2012). Electrochemical Performance of Carbon Nanofibers Containing an Enhanced Dispersion of Silicon Nanoparticles for Lithium-Ion Batteries by Employing Surfactants. ECS Electrochemistry Letters, 1(2), A31-A33. doi: $\underline{10.1149 / 2.002202 \mathrm{eel}}$

Liu, Y., Chae, H.G., Kumar, S., (2011). Gel-spun carbon nanotubes/polyacrylonitrile composite fibers. Part I: Effect of carbon nanotubes on stabilization. Carbon, 49(13), 4466-4476. doi: https://doi.org/10.1016/j.carbon.2011.06.043

Liu, Y., Chae, H.G., Kumar, S., (2011). Gel-spun carbon nanotubes/polyacrylonitrile composite fibers. Part III: Effect of stabilization conditions on carbon fiber properties. Carbon, 49(13), 4487-4496. doi: https://doi.org/10.1016/j.carbon.2011.06.045

Liu, Y., Kumar, S., (2012). Recent progress in fabrication, structure, and properties of carbon fibers. Polymer Reviews 52(3), 234-258. doi: https://doi.org/10.1080/15583724.2012.705410

Mazraeh-Shahi, Z.T., Mojtahedi, M., (2010). Effect of blending two fiber-grade polypropylenes with different molecular weight distributions on the physical and structural properties of melt-spun filament yarns. The Journal of The Textile Institute, 101(6), 547-555. doi: https://doi.org/10.1080/00405000802597600

Morris, E.A., Weisenberger, M.C., (2014). Solution spinning of PAN-based polymers for carbon fiber precursors. Polymer Precursor-Derived Carbon, ACS Symposium Series, 1173, 189-213.

Mukhopadhyay, S., Deopura, B., Alagirusamy, R., (2004). Production and Properties of High-Modulus-HighTenacity Polypropylene Filaments. Journal of Industrial Textiles, 33(4), 245-268. doi: https://doi.org/10.1177/1528083704044905
Journal of Engineering and Architecture Faculty of Eskisehir Osmangazi University 27(2), 130-155, 2019

Najafi, M., Avci, H., Kotek, R., (2015). High-performance filaments by melt spinning low viscosity nylon 6 using horizontal isothermal bath process. Polymer Engineering \& Science, 55(11), 2457-2464. doi: https://doi.org/10.1002/pen.24135

Ohta, T., (1983). Review on processing ultra high tenacity fibers from flexible polymer. Polymer Engineering \& Science, 23(13), 697-703. doi: https://doi.org/10.1002/pen.760231302

Otto, W.H., (1955). Relationship of tensile strength of glass fibers to diameter. Journal of the American Ceramic Society 38(3), 122-125. doi: https://doi.org/10.1111/j.11512916.1955.tb14588.x

Penn, L., Larsen, F. (1979). Physicochemical properties of kevlar 49 fiber. Journal of Applied Polymer Science, 23(1), 59-73. doi: https://doi.org/10.1002/app.1979.070230106

Peters, S.T., (2013). Handbook of composites. Springer Science \& Business Media.

Porter, R.S., Wang, L.-H., (1995). Uniaxial extension and order development in flexible chain polymers. Journal of Macromolecular Science, Part C: Polymer Reviews, 35(1), 63-115. doi: https://doi.org/10.1080/15321799508014590

Reneker, D., Mazur, J., (1983). Dispirations, disclinations, dislocations, and chain twist in polyethylene crystals. Polymer 24(11), 1387-1400. doi: $\quad$ https://doi.org/10.1016/0032$\underline{3861(83) 90219-7}$

Said, M., Dingwall, B., Gupta, A., Seyam, A., Mock, G., Theyson, T., (2006). Investigation of ultra violet (UV) resistance for high strength fibers. Advances in space research, 37(11), 2052-2058. doi: https://doi.org/10.1016/j.asr.2005.04.098

Sakka, S., Kamiya, K., (1982). The sol-gel transition in the hydrolysis of metal alkoxides in relation to the formation of glass fibers and films. Journal of NonCrystalline Solids 48(1), 31-46. doi: https://doi.org/10.1016/0022-3093(82)90244-7

Samuels, R.J., (1968). Quantitative characterization of deformation in drawn polypropylene films. Journal of Polymer Science Part A-2: Polymer Physics, 6(6), 1101-1139. https://doi.org/10.1002/pol.1968.160061207

Schalamon, W., Bacon, R., (1973). Process for producing carbon fibers having a high young's modulus of elasticity. Google Patents.

Severini, F., Formaro, L., Pegoraro, M., Posca, L., (2002). Chemical modification of carbon fiber surfaces. 
Eskişehir Osmangazi Üniversitesi Mühendislik ve Mimarlık Fakültesi Dergisi 27(2), 130 - 155, 2019

Carbon 40(5), 735-741. doi: https://doi.org/10.1016/S0008-6223(01)00180-4

Seyhan, A., Tepekiran, B. N., Polat, Y., Kilic, A., Demir, 1 A., Avci, H., (2019). Development of Crystal Cleavage for Low Molecular Weight Linear Polymer. $5^{\text {th }}$ International Fiber and Polymer Research Symposium, Bursa.

Shaw, M., (1975). Flow of polymer melts through a welllubricated, conical die. Journal of Applied Polymer Science, 19(10), 2811-2816. doi: https://doi.org/10.1002/app.1975.070191016

Sheehan, W., Cole, T., (1964). Production of supertenacity polypropylene filaments. Journal of Applied Polymer Science, 8(5), 2359-2388. doi: https://doi.org/10.1002/app.1964.070080528

Smith, P., Lemstra, P.J., (1979). Ultrahigh-strength polyethylene filaments by solution spinning/drawing, 2. Influence of solvent on the drawability. Die Makromolekulare Chemie: Macromolecular Chemistry and Physics, 180(12), 2983-2986. doi: https://doi.org/10.1002/macp.1979.021801220

Substituent Effects. (2019). Web access server address: http://www.mhhe.com/physsci/chemistry/carey/s tudent/olc/graphics/carey04oc/ref/ch12substitue nteffects.html.

Taylor Jr, W., Clark, E., (1978). Superdrawn filaments of polypropylene. Polymer Engineering \& Science, 18(6), 518-526. doi: https://doi.org/10.1002/pen.760180615

Ugbolue, S.C.O., (2009). Polyolefin Fibres: Industrial and Medical Applications. Elsevier.

Ultraviolet radiation and health. (2019). Web access server address: http://www.who.int/uv/uv and health/en/.

Vectran Fiber. UV Resistance. (2019). Web access server address:

<http://www.vectranfiber.com/BrochureProductIn formation/UVResistance.aspx $>$.

Wang, L., Yu, Y., Chen, P.-C., Chen, C.-H., (2008). Electrospun carbon-cobalt composite nanofiber as an anode material for lithium ion batteries. Scripta Materialia, 58(5), 405-408. doi: https://doi.org/10.1016/j.scriptamat.2007.10.024

Wang, S., Ma, S., Li, Q., Xu, X., Wang, B., Yuan, W., Zhou S., You S., Zhu, J., (2019). Facile in situ preparation of high-performance epoxy vitrimer from renewable resources and its application in nondestructive recyclable carbon fiber composite. Green Chemistry, 21(6), 1484-1497. doi: 10.1039/C8GC03477I
Journal of Engineering and Architecture Faculty of Eskisehir Osmangazi University 27(2), 130-155, 2019

Watts, W.H., (1968). Process of producing carbonized articles. Google Patents.

Wen, H.-C., Yang, K., Ou, K.-L., Wu, W.-F., Chou, C.-P., Luo, R.-C., Chang, Y.-M., (2006). Effects of ammonia plasma treatment on the surface characteristics of carbon fibers. Surface and Coatings Technology, 200(10), 3166-3169. doi: https://doi.org/10.1016/j.surfcoat.2005.07.036

$\mathrm{Xu}, \mathrm{T} .$, Farris, R.J., (2007). Comparative studies of ultra high molecular weight polyethylene fiber reinforced composites. Polymer Engineering \& Science, 47(10), 1544-1553.

doi: https://doi.org/10.1002/pen.20876

Xu, Z., Wu, X., Sun, Y., Jiao, Y., Li, J., Chen, L., Lu, L., (2008). Surface modification of carbon fiber by redoxinduced graft polymerization of acrylic acid. Journal of Applied Polymer Science 108(3), 1887-1892. doi: https://doi.org/10.1002/app.27874

y Léon, C.A.L., (2010). Carbon fibers having improved strength and modulus and an associated method and apparatus for preparing same. Google Patents.

Yamada, K., Kamezawa, M., Takayanagi, M., (1981). Relationship between orientation of amorphous chains and modulus in highly oriented polypropylene. Journal of Applied Polymer Science, 26(1), 49-60. doi: https://doi.org/10.1002/app.1981.070260106

Yoon, J.H., Avci, H., Najafi, M., Nasri, L., Hudson, S.M., Kotek, R., (2017). Development of high-tenacity, high-modulus poly (ethylene terephthalate) filaments via a next generation wet-melt-spinning process. Polymer Engineering \& Science, 57(2), 224230. doi: https://doi.org/10.1002/pen.24406

Yue, Y., Von der Ohe, R., Jensen, S.L., (2004). Fictive temperature, cooling rate, and viscosity of glasses. The Journal of Chemical Physics, 120(17), 8053-8059. doi: https://doi.org/10.1063/1.1689951

Yue, Z., Jiang, W., Wang, L., Gardner, S., Pittman Jr, C., (1999). Surface characterization of electrochemically oxidized carbon fibers. Carbon, 37(11), 1785-1796. doi: https://doi.org/10.1016/S0008-6223(99)00047-0 